
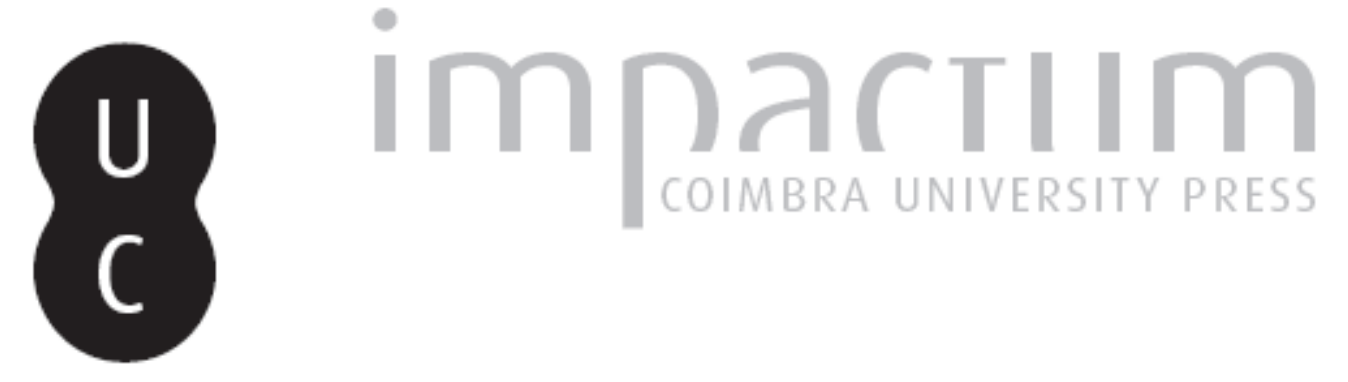

\title{
La disputa entre el episcopado y la nobleza por los beneficios eclesiásticos en Galicia en el siglo XVI (1482-1598)
}

\author{
Autor(es): $\quad$ Presedo Garazo, Antonio
}

Publicado por: Imprensa da Universidade de Coimbra

URL persistente:

URI:http://hdl.handle.net/10316.2/35442

DOI:

DOI:http://dx.doi.org/10.14195/0870-4147_45_23

Accessed : $\quad$ 26-Apr-2023 14:50:02

A navegação consulta e descarregamento dos títulos inseridos nas Bibliotecas Digitais UC Digitalis, UC Pombalina e UC Impactum, pressupõem a aceitação plena e sem reservas dos Termos e Condições de Uso destas Bibliotecas Digitais, disponíveis em https://digitalis.uc.pt/pt-pt/termos.

Conforme exposto nos referidos Termos e Condições de Uso, o descarregamento de títulos de acesso restrito requer uma licença válida de autorização devendo o utilizador aceder ao(s) documento(s) a partir de um endereço de IP da instituição detentora da supramencionada licença.

Ao utilizador é apenas permitido o descarregamento para uso pessoal, pelo que o emprego do(s) título(s) descarregado(s) para outro fim, designadamente comercial, carece de autorização do respetivo autor ou editor da obra.

Na medida em que todas as obras da UC Digitalis se encontram protegidas pelo Código do Direito de Autor e Direitos Conexos e demais legislação aplicável, toda a cópia, parcial ou total, deste documento, nos casos em que é legalmente admitida, deverá conter ou fazer-se acompanhar por este aviso.

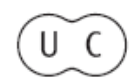




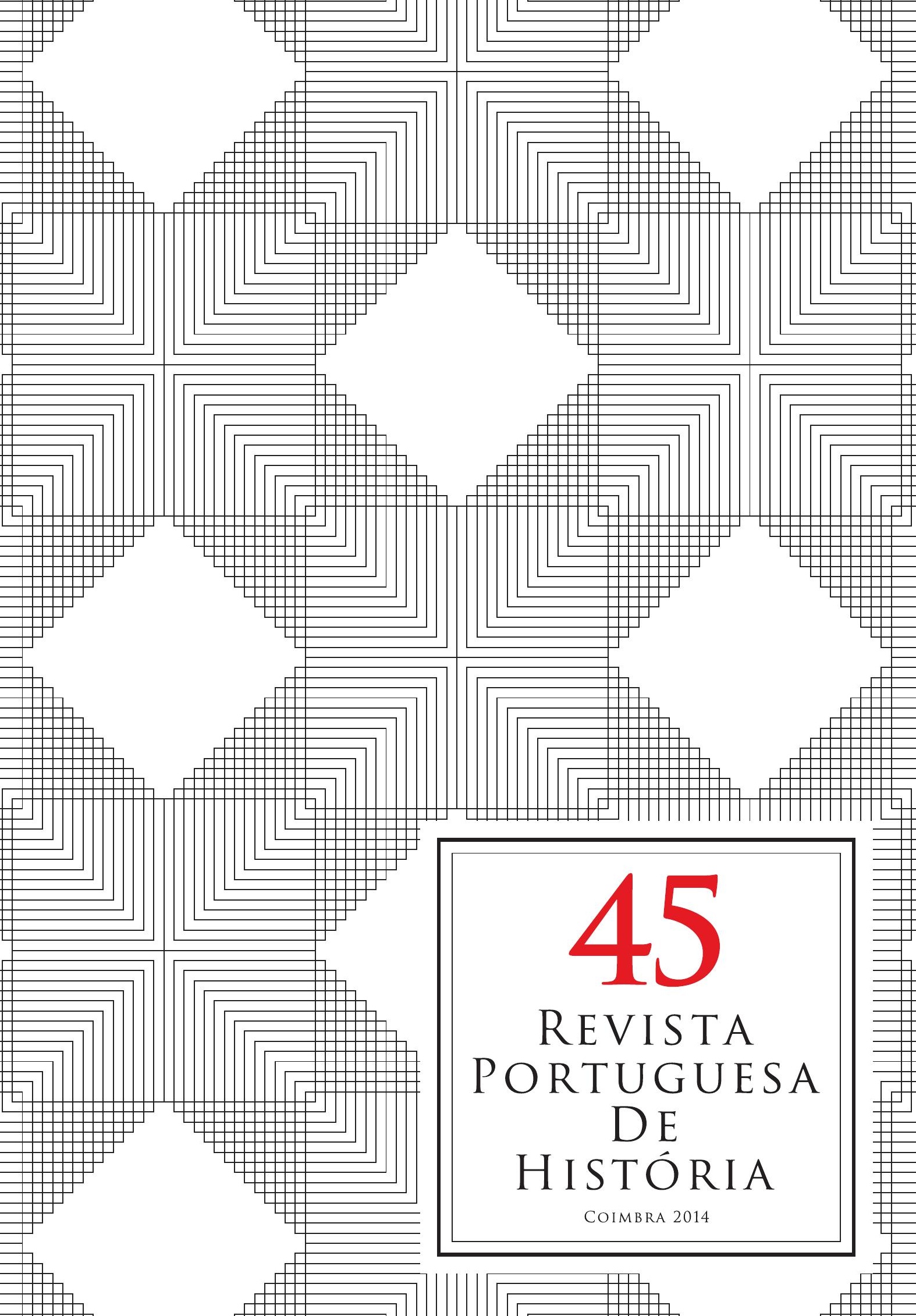




\title{
La disputa entre el episcopado y la nobleza por los beneficios eclesiásticos en Galicia en el siglo XVI (1482-1598)*
}

\author{
The dispute between bishops and noblemen for parochial benefices \\ in the Sixteenth century Galicia (1482-1598)
}

\author{
Antonio Presedo Garazo \\ Profesor Asociado de Historia Moderna en la Universidad de Vigo (España) \\ antonio.presedo@uvigo.es
}

Resumen:

En el siglo XVI, el episcopado gallego y las casas nobles que habían consolidado sus patrimonios en Galicia durante la Baja Edad Media protagonizaron un enfrentamiento por la posesión y usufructo de los beneficios parroquiales. Del mismo modo que otras instituciones eclesiásticas, como monasterios, colegiatas y cabildos catedralicios, los obispos se quejaron ante la justicia real de la apropiación indebida que de dichos bienes habían realizado nobles e hidalgos, y reclamaron su devolución. Por su parte, las casas nobiliarias argumentaban que la pérdida de los bienes procedentes de las instituciones eclesiásticas, y especialmente los ingresos obtenidos de los beneficios parroquiales, representaría graves pérdidas, incluso irreparables, para sus haciendas privadas. En las páginas que siguen se ha planteado el estudio de las etapas y claves de este conflicto que, iniciado a finales del siglo $\mathrm{XV}$, se prolongará durante todo el XVI, y en algunos casos incluso durante el XVII, cuyo desenlace favorecerá a la nobleza.
Abstract:

At the Sixteenth century, Galician bishops and noblemen were feuding because of the property and the usufruct of parochial benefices. As other ecclesiastic institutions, like monasteries, collegiate churches and cathedral chapters, the bishops reported their goods that were took illegally by nobles and hidalgos to the royal jurisdiction, and they asked for these goods to be given back. In the other hand, the noblemen argued that the loss of these goods from ecclesiastic institutions, and the incomes from parochial benefices mainly, would cause serious losses for their resources. In this article, we analyze the stages and the keys to this dispute that began at the end of the Fifteenth century and it went out during the Sixteenth century and even in the Seventeenth century in some cases, which ending was favourable to the nobility.

Keywords:

bishops; nobility; parochial benefice; diocese; dispute.

Palabras clave:

obispos; nobleza; beneficio parroquial; diócesis; disputa.

* Trabajo realizado en el marco del Proyecto de Investigación "Parroquia y comunidad rural en Galicia, c.1450-c.2000”, código: HAR2009-13304/HIST, financiado por el Ministerio de Economía y Competitividad (MINECO) y dirigido por Pegerto Saavedra Fernández. 


\section{Introducción}

Los estudios que han realizado hasta el presente los historiadores modernistas sobre el episcopado gallego en el transcurso de la Alta Edad Moderna, se han centrado principalmente en el perfil sociológico de los obispos y el papel que éstos desempeñaron en la aplicación del programa reformador que impulsó el Concilio de Trento, junto con otras iniciativas episcopales previas, con el objeto de reformar la conducta y mejorar la formación del clero parroquial, al cual se acusaba de estar poco comprometido con sus obligaciones pastorales y llevar un estilo de vida aseglarado ${ }^{1}$. Asimismo, el episcopado gallego del siglo XVI e inicios del XVII también ha despertado interés por su condición señorial. El arzobispo de Santiago era entonces el principal señor jurisdiccional gallego, y tanto éste como el obispo de Mondoñedo figuran entre los diez principales señores de vasallos a mediados del siglo $\mathrm{XVIII}^{2}$, disponiendo por ello de gran poder en el ámbito regional ${ }^{3}$. Incluso los núcleos urbanos en que se hallan ambas sedes diocesanas, que actuarán a la vez como capitales de provincia cuando el territorio galaico sea dividido en estas circunscripciones administrativas - primero en cinco (1526) y luego siete

\footnotetext{
${ }^{1}$ Vid. Domingo L. González Lopo, "El alto clero gallego en tiempos de Felipe II" in A. Eiras Roel (coord.), El reino de Galicia en la monarquía de Felipe II, Santiago de Compostela, Xunta de Galicia, 1998, p. 313-343 y "El episcopado gallego en tiempos de Carlos V" in A. Eiras Roel (coord.), El reino de Galicia en la época del emperador Carlos V, Santiago de Compostela, Xunta de Galicia, 2000,p. 135-169; y Baudilio Barreiro Mallón, "El clero secular gallego en tiempos del cardenal Rodrigo de Castro" in Xornadas sobre o cardeal Rodrigo de Castro, Santiago de Compostela, Xunta de Galicia, 2001, p. 106-114. Para las tres centurias modernas, especialmente el período 1600-1649, vid. Maximiliano Barrio Gozalo, "Perfil socioeconómico de una élite de poder: Los Obispos del Reino de Galicia (1600-1840)", Anthologica Annua, 32 (1985), p. 11-107. Para un análisis comparativo de la sociología episcopal, vid. en relación con los obispos de las 11 diócesis de Castilla y León, Maximiliano Barrio Gozalo, Los obispos de Castilla y León durante el Antiguo Régimen, Zamora, Junta de Castilla y León, 2000 , p. 25 y ss.

${ }^{2}$ Antonio Eiras Roel, "El señorío gallego en cifras. Nómina y ranking de los señores jurisdiccionales", Cuadernos de Estudios Gallegos, XXXVIII (1989), p. 125-126.

${ }^{3}$ Un estudio en profundidad de la justicia señorial del arzobispo compostelano y del obispo lugués en los siglos XVI y XVII, en María López Díaz, Señorío y Municipalidad. Concurrencia y conflicto de poderes en la ciudad de Santiago (siglos XVI-XVII), Santiago de Compostela, Universidad de Santiago de Compostela y Consorcio de Santiago, 1997, parte 2. a , p. 213 y ss.
} 
$(1552)^{4}-$, estaban sometidas a la jurisdicción episcopal, de igual modo que las ciudades de Lugo y Tui ${ }^{5}$.

No obstante, aún no se han analizado las claves de la disputa con la nobleza en que se vieron envueltos los obispos gallegos -junto con los demás sectores del alto clero regional- en los inicios de la Edad Moderna, motivada por la posesión y usufructo que aquella venía realizando de los beneficios parroquiales, sobre todo después del fortalecimiento del régimen de patronato laical que se produce en el conjunto de la Iglesia española durante el reinado de Enrique IV (r.1454-1474) ${ }^{6}$, al que no fueron ajenas las diócesis gallegas. Los nobles poseían entonces una gran capacidad de actuación en las parroquias rurales, derivada de la riqueza que habían acumulado en los siglos bajomedievales; $y$ en la medida en que los derechos de las iglesias parroquiales representaban una parte destacada de ésta (materializada en la percepción del diezmo y otras rentas eclesiásticas como la primicia y las ofrendas, e incluso en algunos casos en el cobro de yantares) $)^{7}$, no siempre contando para ello con la aprobación eclesiástica, dicha circunstancia propició la aparición de abundantes conflictos en los cuales emergieron intereses contrapuestos y que dieron lugar a una controversia de mayor calado.

En su origen resultó decisiva la bula emitida por Nicolás V en 1453, según la cual se protegía a la Iglesia gallega de aquellos laicos que se habían aventurado a propasarse en sacar provecho de los beneficios eclesiásticos. La secuencia del conflicto en torno al problema beneficial que se inicia abiertamente cuando el concilio o asamblea del clero castellano celebrado Sevilla en 1478 se hace eco de los graves problemas que representaba dicha situación para el clero gallego ${ }^{8}$, fue magistralmente elaborada en su día por José García Oro

\footnotetext{
${ }^{4}$ Esta división del territorio gallego en provincias debe ser puesta en relación con la profunda reestructuración que experimenta el sistema fiscal castellano en la década de los años veinte del siglo XVI. Vid. Antonio Eiras Roel, "Las Juntas del Reino de Galicia: orígenes y proceso de institucionalización”, Obradoiro de Historia Moderna, 4 (1995), p. 128-141.

${ }^{5}$ Se trata de cuatro capitales de provincia sobre un total de siete en que se divide Galicia a partir de 1552. La ciudad Ourense, bajo señorío episcopal al inicio de esta época histórica, pasará definitivamente al realengo en 1628. Vid. María López Díaz, Jurisdicción e Instituciones locales de la Galicia meridional (XVI-XVIII), Vigo, Universidad de Vigo, 2011, p. 75 y ss.

${ }^{6}$ Elena Catalán Sanz, "El derecho de patronato y el régimen beneficial de la Iglesia española en la Edad Moderna", Hispania Sacra, 56 (2004), p. 147-148.

${ }^{7}$ Ana M. ${ }^{a}$ Framiñán Santas, "Notas acerca de los derechos de los laicos en las iglesias parroquiales de Galicia (s. XII-XV)", Estudios Mindonienses, 21 (2005), p. 327-334.

${ }^{8}$ Téngase en cuenta que esta asamblea o congregación general del clero castellano, reunida en Sevilla en 1478, no solo se ocupó de la reforma disciplinar del clero castellano, sino que también obedece a una motivación política, tal como ha señalado F. Javier Villalba Ruiz de Toledo,
} 
para la etapa comprendida por el reinado de los Reyes Católicos (1474-1516). La intervención de los monarcas castellanos contribuyó a que los nobles no saliesen del todo malparados, habida cuenta del equilibrio de fuerzas por el que se decantaron en su resolución. En 1493, consiguieron que el sumo pontífice Alejandro VI emitiese una nueva bula, por la cual se dispensaba a los legos del aprovechamiento que venían haciendo y hacían de dichos beneficios en compensación por el servicio que, a su vez, habían hecho y hacían a las fábricas parroquiales ${ }^{9}$. A cambio, algunos de ellos deberán hacer frente a las consecuencias derivadas de la restauración de las haciendas monacales, propiciada por la reforma del monacato gallego, cuya segunda etapa se inicia justo un año después, en el tercer cuarto de 1494, y que aumenta su ritmo a partir de $1505^{10}$. Sin embargo, todavía no se ha profundizado en el posterior desarrollo de este litigio ni en las consecuencias que su resolución tuvo para las dos partes implicadas en la media duración, con la excepción de un trabajo que debemos a María Jesús Baz Vicente ${ }^{11}$. Es por ello que nos hemos propuesto elaborar en el presente artículo una primera aproximación a cuáles fueron las claves y etapas de dicho conflicto de naturaleza jurisdiccional y económica, puesto que está motivado por la titularidad del derecho de patronato y los ingresos que genera el régimen beneficial ${ }^{12}$.

Para cumplir con nuestro objetivo, intentaremos comprobar qué grado de intervencionismo fueron capaces de alcanzar y mantener las casas nobles e

puesto que debía contribuir "a legitimar por la vía del compromiso del estamento eclesiástico, la situación en el trono de Castilla de los Reyes Católicos”. Vid. El cardenal Mendoza (14281495), Madrid, Rialp, 1988, p. 127-134.

${ }^{9}$ José García Oro, Señorío y nobleza. Galicia en la Baja Edad Media, Santiago de Compostela, El Eco Franciscano, 1977, p. 212-218.

${ }^{10}$ Camilo Fernández Cortizo, "La Orden de San Benito en la Galicia de la época moderna: La reforma de la Congregación de Castilla y las visitas generales” in José Manuel López Vázquez (coord.), Opus Monasticorum. Patrimonio, Arte, Historia y Orden, Santiago de Compostela, Xunta de Galicia, 2005, p. 23-41; y Antonio Presedo Garazo, "Las casas nobles gallegas y su relación con los monasterios de la Diócesis de Santiago de Compostela en la temprana Edad Moderna (1454-1556)" in Raquel Casal et al. (eds.), Galicia Monástica. Estudos en lembranza da profesora María José Portela Silva, Santiago de Compostela, Universidad de Santiago de Compostela, 2009, p. 237-243.

${ }^{11}$ María Jesús Baz Vicente, "Los dominios y prebendas eclesiásticas de la alta nobleza en Galicia: la historia de una integración frustrada", Cuadernos de Estudios Gallegos, 110 (1998), p. 73-118. Esta autora no sólo centra su análisis en la disputa por la posesión y usufructo de los beneficios parroquiales, sino también por los bienes de naturaleza jurisdiccional y territorial que las casas nobles habían recibido y/o usurpado a la Iglesia gallega en su conjunto.

${ }^{12}$ Tanto para el derecho de patronato como para el régimen beneficial, vid. Elena Catalán Sanz, "El derecho de patronato...", cit., p. 135 y ss. 
hidalgas en aquellas iglesias parroquiales que se hallaban bajo su órbita de influencia, y, complementariamente, desde la perspectiva episcopal, en qué medida consiguieron los prelados restaurar su potestad sobre los beneficios parroquiales en disputa. Las fuentes que hemos empleado proceden, por una parte, de archivos históricos en los cuales se conservan fondos eclesiásticos de las mitras y los cabildos catedralicios gallegos, y por otra, de archivos nobiliarios que ofrezcan información sobre la materia de nuestro interés; ora se trate de fuentes primarias, ora de fuentes ya editadas; junto con la valiosa información que aporta la bibliografía dedicada a la nobleza e Iglesia gallegas en los siglos XV y XVI ${ }^{13}$. Dentro de éstas, nos han interesado muy especialmente aquellas que se hacen eco de la actividad judicial desarrollada en torno a dicho conflicto y las visitas pastorales, puesto que estas segundas informan acerca de a quién corresponde el derecho de presentación en las iglesias parroquiales visitadas. Tal como veremos, la capacidad de respuesta de los obispos y las casas nobles implicadas en cada caso influyó notablemente en la resolución de los litigios planteados.

\section{Origen y consolidación del conflicto, 1482-1520}

La expansión de los dominios de la nobleza castellana en los siglos bajomedievales experimenta un avance notable desde que la dinastía Trastámara accede al trono en 1369; un proceso que, en el caso gallego, alcanza su cenit durante el reinado de Enrique IV, coincidiendo con la inestabilidad política que se vive entonces en la Corona de Castilla y que es aprovechada por los principales linajes nobiliarios para incrementar su poder sobre las bases patrimoniales solidamente constituidas durante los reinados precedentes de dicha dinastía ${ }^{14}$. Las casas nobles oriundas gallegas que estaban en condiciones de

${ }^{13}$ El lector podrá encontrar amplia información sobre dichas fuentes archivísticas y bibliográficas en las páginas que siguen del presente artículo, así como de las limitaciones que éstas presentan para el estudio de la temática que nos ocupa, entre las cuales merece ser destacado el inconveniente que representa el hecho de que se haya conservado poca documentación histórica sobre la misma para antes del Concilio de Trento.

${ }^{14}$ María José García Vera, "Poder nobiliario y poder político en la Corte de Enrique IV (1454-1474)", En la España Medieval, 16 (1993),p. 223-237. Las monografías en las que se analiza la expansión nobiliaria castellana tras la llegada al trono de la dinastía Trastámara han constatado este proceso. Así, los Quiñones del condado de Luna, tras las mercedes regias recibidas a finales del siglo XIV y la fundación del mayorazgo en 1442, acceden al título condal durante el reinado de Enrique IV en reconocimiento de sus servicios (vid. César Álvarez Álvarez, El Condado de Luna en la Baja Edad Media, León, 1982, p. 48, 52-70 y 141-150); del mismo modo que los Osorio del marquesado de Astorga, que se hacen con el título del marquesado en 1465 (vid. José 
ampliar sus dominios también participaron en este reforzamiento nobiliario en la etapa Trastámara -como por ejemplo Altamira, Andrade y Montaos ${ }^{15}$, uniéndoseles otras procedentes de Castilla que logran extender los suyos a lo largo del territorio galaico desde el último cuarto del siglo XIV y durante todo el XV -entre ellas, Benavente y Ribadavia ${ }^{16}$-. Su expansión no habría sido posible en Galicia sin los bienes y derechos de diversa índole procedentes de las iglesias catedrales y las instituciones regulares ${ }^{17}$, tal como ha sido puesto

Antonio Martín Fuertes, De la nobleza leonesa. El Marquesado de Astorga, Madrid, Hullero Vasco-Leonesa, 1988, p. 59), o los Sotomayor del condado de Belalcázar, que, luego de fundar el mayorazgo en 1453, se hacen con el título condal al menos desde 1466 en el contexto de la consolidación de su dominio solariego durante el siglo XV (vid. Emilio Cabrera Muñoz, El condado de Belalcázar (1444-1518). Aportación al estudio del régimen señorial en la Baja Edad Media, Córdoba, 1977, p. 108 y ss., 164 y 263 y ss.). Por su parte, la consolidación del patrimonio del condado de Benavente que protagoniza el IV conde, don Rodrigo Alfonso Pimentel, quien estuvo al frente de dicha casa condal entre 1461-1499, coincide con el reinado de Enrique IV y sus sucesores, los Reyes Católicos (vid. Isabel Beceiro Pita, El Condado de Benavente en el siglo XV, Benavente, CECEL-CSIC, 1998, p. 183 y ss.); y los Guzmán de Medina Sidonia, después acceder al título ducal en 1445, fundan un nuevo mayorazgo en 1457 y amplían su patrimonio a lo largo del mencionado reinado enriqueño (vid. Isabel Galán Parra, "El linaje y los estados señoriales de los duques de Medina Sidonia a comienzos del siglo XVI", En la España Medieval, 11 (1988), p. 49-52). Vid. además Alfonso Franco Silva, Grajal de Campos. Un señorío leonés en la baja Edad Media, Cádiz, Universidad de Cádiz, 2001, p. 45-63.

15 José García Oro y María José Portela Silva, La Casa de Altamira durante el Renacimiento. Estudio y colección diplomática, Santiago de Compostela, El Eco Franciscano, 2003, p. 17 y ss.; José García Oro, Don Fernando de Andrade, Conde de Villalba (1477-1540), Santiago de Compostela, Xunta de Galicia, 1994, p. 19 y ss.; y Antonio Presedo Garazo, Nobleza y régimen señorial en Galicia. La Casa Montaos en los siglos XVI y XVII, Santiago de Compostela, USC Editora, 2011, p. 62 y ss.

${ }^{16}$ Isabel Beceiro Pita, El Condado de Benavente..., cit.; y Gonzalo F. Fernández Suárez, La Nobleza Gallega entre los siglos XIV-XV. Los Sarmiento Condes de Ribadavia, Santiago de Compostela, El Eco Franciscano, 2002, p. 86 y ss.

${ }^{17}$ Esta injerencia nobiliaria en el patrimonio eclesiástico no fue exclusiva de Galicia, sino que también es posible observarla en otros territorios de la Corona de Castilla. Vid. para Soria, La Rioja y Córdoba, sucesivamente, Máximo Diago Hernando, "El factor religioso en la actividad política y social de los linajes de la alta nobleza en la región de Soria a fines de la Edad Media", Hispania Sacra, 127 (2011), p. 23-26 y "El poder de la nobleza en los ámbitos regionales de la Corona de Castilla a fines del Medievo: las estrategias políticas de los grandes linajes en La Rioja hasta la revuelta comunera", Hispania. Revista Española de Historia, 223 (2006), p. 527 534; y María del Mar Graña Cid, "Poder nobiliario y monacato femenino en el tránsito a la Edad Moderna (Córdoba, 1495-1550)", Cuadernos de Historia Moderna, 37 (2012), p. 43-72. Para la tutela nobiliaria de los Velasco sobre el monasterio benedictino de San Salvador de Oña, vid. Máximo Diago Hernando, "La tutela nobiliaria sobre los monasterios benedictinos castellanos en la Baja Edad Media: relaciones entre los Velasco y el monasterio de San Salvador de Oña", Hispania Sacra, 56 (2004), p. 69-102. 
de manifiesto en las investigaciones llevadas a cabo sobre las casas indicadas, llegando a superar en ocasiones a los aportados por otras vías de expansión dominial igualmente relevantes para la nobleza, como las mercedes regias, las adquisiciones y el mercado matrimonial. Por ello no dudan en incorporar a sus patrimonios la jurisdicción sobre cotos de una extensión variable que el clero ha puesto en sus manos en régimen de encomienda o a través de otras fórmulas feudovasalláticas, el dominio útil de lotes de tierras eclesiásticas destinadas a la explotación agrícola recibidos en foro, y los ingresos generados por los beneficios eclesiásticos de las iglesias parroquiales en las cuales ejercen el derecho de patronato, bien en las jurisdicciones que han recibido del clero, o bien en aquellas otras a cuyo señorío han accedido a través de las otras vías ya señaladas ${ }^{18}$.

Fue el intento continuado de patrimonialización de estos bienes, unido a los episodios reiterados de desobediencia hacia los señores eclesiásticos de quienes los habían recibido, que van más allá del incumplimiento puntual de algunas cláusulas de los documentos de cesión dominial -puesto que no suelen ser ajenas a las relaciones políticas que se constituyen a partir de las complejas alianzas en las cuales se posicionan tanto nobles como alto clero ${ }^{19}-$, lo que dio lugar a las reivindicaciones del clero gallego que ya se pueden documentar a fines del siglo XIV, en las que se acude a la justicia real para solicitar su reintegro ${ }^{20}$. Éstas irán en aumento conforme avance la primera mitad del $\mathrm{XV}$ y la expansión de las haciendas nobiliarias exija de un mayor nivel de intrusismo en el patrimonio eclesiástico, para culminar en la celebración del concilio o asamblea del clero castellano de Sevilla de 1478, a través del cual dicho estamento legitima en el trono a los Reyes Católicos ${ }^{21}$. Fue entonces cuando los obispos y los cabildos catedralicios gallegos se plantearon seria-

${ }^{18}$ Abundantes ejemplos de ello en la bibliografía citada en las notas 15 y 16, y, asimismo, en Antonio Presedo Garazo, "Las casas nobles gallegas...", cit. y María Jesús Baz Vicente, "Los dominios y prebendas eclesiásticas...", cit.

${ }^{19}$ Para contextualizar dichas alianzas entre las distintas casas nobiliarias en la Galicia de los siglos XIV y XV, y las relaciones de éstas con las instituciones eclesiásticas, vid. José García Oro, La nobleza gallega en la Baja Edad Media. Las casas nobles y sus relaciones estamentales, Santiago de Compostela, Bibliófilos Gallegos, 1981.

${ }^{20}$ Así, por ejemplo, antes de 1380, los monasterios coruñeses de Caaveiro y Sobrado ya habían presentado reclamaciones ante Juan I solicitando la restitución de bienes que estaban en manos del linaje Andrade. Vid. José García Oro, Don Fernando de Andrade..., cit. p. 22-23.

${ }^{21}$ F. Javier Villalba Ruiz de Toledo, El cardenal Mendoza..., cit., p. 128. Sobre los conflictos entre nobleza e Iglesia por el reparto de las rentas decimales en el obispado de Cuenca en este mismo contexto cronológico, vid. Jorge Díaz Ibáñez, "Las relaciones Iglesia-Nobleza en el obispado de Cuenca durante la Baja Edad Media", En la España Medieval, 20 (1997), p. 281-286. 
mente la recuperación de los bienes cuya posesión consideraban les había sido substraída a consecuencia del expansionismo nobiliario, con el objeto de sanear sus haciendas y recobrar con ello el poder económico perdido.

Un breve repaso a los pontificados de los obispos que se suceden en las cinco iglesias catedrales galaicas y los ingresos que debían percibir sus mesas episcopales, durante el período de tiempo que abarca desde el reinado de Enrique II (r.1369-1379) - que da inicio a la mencionada dinastía Trastámara-hasta la celebración de la asamblea o congregación general del clero castellano en 1478, valiéndonos para ello de bibliografía especializada, nos ayudará contextualizar mejor estas reivindicaciones para valorar su alcance. En la Galicia atlántica, son 7 los arzobispos que se sitúan al frente de la archidiócesis de Santiago de Compostela a lo largo del período contemplado ${ }^{22}$. La hacienda arzobispal estaba compuesta por un amplio patrimonio territorial (que le permite disponer de derechos de propiedad que generan sus casales) y señorial (que incluye el ejercicio de justicia en el señorío más extenso de Galicia; una variada gama de rentas de reconocimiento de vasallaje, como el yantar, la luctuosa o la fonsadera, entre otras; y el cobro de portazgos en determinadas localidades), la percepción de rentas procedentes de la hacienda real (alcabala, diezmas del mar, diezma sobre la sal y el cobro de juros situados sobre rentas reales), e ingresos de carácter eclesiástico (principalmente el Voto de Santiago, los derechos sobre beneficios eclesiásticos difícilmente cuantificables, las visitaciones y procuraciones y el servicio denominado catedratico o sinodatico ${ }^{23}$. Más al sur, un total de 13 obispos rigen la Iglesia Catedral de Tui en este período ${ }^{24}$. Sus ingresos, muy por debajo de los de la mesa arzobispal

${ }^{22}$ Estos siete arzobispos compostelanos son: Rodrigo de Moscoso (1367-1382), Juan García Manrique (1382-1398), Lope de Mendoza (1399-1445), Álvaro Núñez de Isorna (1445-1449), Rodrigo de Luna (1449-1460), Alonso de Fonseca I (1460-1464) y Alonso de Fonseca II (14641506). Vid. María José Portela Silva, “Apéndice. 1. Episcopologio” in José García Oro (coord.), Historia de las diócesis españolas. Vol. 14. Santiago de Compostela y Tuy-Vigo, Madrid, Biblioteca de Autores Cristianos, 2002, Primera parte: La Iglesia de Santiago de Compostela, p. 521.

${ }^{23}$ Mercedes Vázquez Bertomeu, La Hacienda Arzobispal Compostelana. Libros de recaudación (1481-83 y 1486-91), Santiago de Compostela, Instituto de Estudios Gallegos Padre Sarmiento, 2002, p. 25-51. Para la primera mitad del siglo XV, vid. Ángel Rodríguez González (ed.), O Tumbo Vermello de don Lope de Mendoza, Santiago de Compostela, Instituto de Estudios Gallegos Padre Sarmiento, 1995; y para la justicia señorial del arzobispo compostelano en el XVI, María López Díaz, Señorío y Municipalidad..., parte 2. ${ }^{\text {a }, ~ p . ~} 213$ y ss.

${ }^{24}$ Estos trece obispos tudenses son: Juan de Castro (1351-1383), Diego de Anaya Maldonado (1384-1390), Juan Ramírez de Guzmán (1390-1394), Juan García Manrique (1394-1406), Juan Fernández de Soutomaior (1406-1423), Diego Rapado (1424-1425), Rodrigo de Torres (1425), Pedro (1429-1437), García Martínez de Baamonde (1437-1440), Luís Pimentel (1440-1467), 
compostelana, siguen no obstante un esquema similar a grandes rasgos, con un patrimonio territorial que le permite disponer de rentas forales, un señorío que genera rentas vasalláticas, privilegios reales (procedentes de la venta del vino, las barcas, el portazgo y la pesca) y derechos eclesiásticos (entre los cuales se halla el tercio que le corresponde del diezmo diocesano) ${ }^{25}$. En la Galicia cantábrica, son 9 los mitrados que se suceden al frente de la diócesis de Mondoñedo ${ }^{26}$. La falta de estudios sobre la hacienda episcopal mindoniense para esta época no nos permite realizar una aproximación a su composición ${ }^{27}$, si bien es muy probable que ya entonces tampoco generase -al igual que la tudense - unos ingresos de consideración, habida cuenta de que, tal como puso de manifiesto Pegerto Saavedra para el siglo XVI, en 1533 se situaban en 1.500 ducados y, dos décadas más tarde, en 1557, en 3.00028. A su vez, en la Galicia oriental y al sur de la precedente, otros 9 obispos se sucedieron al frente de la Iglesia Catedral de Lugo ${ }^{29}$. Aunque tampoco se dispone todavía de una investigación en la que se analice en detalle la mesa episcopal entre 1369 y 1478, durante el siglo XVI el mitrado lugués dispone de un patrimonio modesto que

Rodrigo de Vergara (1467-1469), Pedro Parezes (1469-1472) y Diego de Muros (1472-1487). Vid. María José Portela Silva, “Apéndice. 1. Episcopologio” in José García Oro (coord.), Historia de las diócesis..., cit., vol. 14, Segunda parte: La Iglesia de Tuy-Vigo, p. 715.

${ }^{25}$ María del Carmen Sánchez Carrera, El Bajo Miño en el siglo XV. El espacio y los hombres, A Coruña, Fundación Pedro Barrié de la Maza, 1997, p. 232.

${ }^{26}$ Estos nueve obispos mindonienses son: Francisco (1367-1393), Lope de Mendoza (13931399), Álvaro Núñez de Isorna (1399-1415), Gil Soutelo (1415-1426), Pedro Enríquez de Castro (1427-1445), Pedro Arias de Baamonde (1446-1448), Alfonso de Segura (1449-1455), Alfonso Vázquez de Acuña (1455-1457) y Fadrique de Guzmán (1457-1493). Vid. Enrique Cal Pardo, Episcopologio mindoniense, Santiago de Compostela, Instituto de Estudios Gallegos Padre Sarmiento, 2003, p. 174 y ss.

${ }^{27}$ Sí han sido estudiadas las relaciones entre el obispo y el cabildo catedralicio mindonienses con los nobles que extienden sus patrimonios a lo largo del territorio diocesano, por José García Oro, Señorío y nobleza..., cit., pp. 55-61 y "La Iglesia de Mondoñedo e el siglo XIV" in Manuel Alfonso Valín Valdés et al. (coords.), O Mariscal Pardo de Cela e o seu tempo, Lugo, Diputación Provincial de Lugo, 2006, p. 476 y ss.

${ }^{28}$ Pegerto Saavedra Fernández, Economía, Política y Sociedad: La provincia de Mondoñedo, 1480-1830, Madrid, Xunta de Galicia, 1985, p. 546-547. Vid. además Domingo L. González Lopo, "El episcopado gallego...”, cit., p. 138.

${ }^{29}$ Estos nueve obispos lugueses son: Pedro López de Aguiar (1349-1390), Lope (1390-1403), Frei Juan Freijo (1403-1409), Juan Enríquez (1409-1418), Fernando de Palacios (1418-1434), Álvaro Pérez Osorio (1434-1440), García Martínez de Baamonde (1440-1445 y 1447-1475), Pedro de Silva (1445-1447) y Alonso Enríquez (1476-1495). Vid. María José Portela Silva, “Apéndice. 1. Episcopologio lucense" in José García Oro (coord.), Historia de las diócesis españolas. Vol. 15. Lugo, Mondoñedo-Ferrol y Orense, Madrid, Biblioteca de Autores Cristianos, 2002, Primera parte: La Iglesia de Lugo, p. 521. 
da cabida a casales y lugares, además de fincas sueltas, inmuebles situados en la ciudad de Lugo y en algunas localidades rurales de esta diócesis (incluidos diversos pazos) y otros bienes de naturaleza territorial cuyo usufructo se suele ceder en foro; asimismo, cuenta con un señorío de nivel medio que le permite ejercer justicia, ingresar derechos señoriales con una gran carga simbólica, y percibe además derechos eclesiásticos, entre los cuales figura el diezmo ${ }^{30}$. En quinto y último lugar, se sitúan al frente de la diócesis de Ourense, al sur de la luguesa, 17 obispos $^{31}$. De nuevo, al igual que en los tres casos precedentes, sus ingresos son muy inferiores a los del mitrado compostelano, aunque muestran una composición análoga, en la cual se combinan el patrimonio territorial, concentrado principalmente en los cotos localizados en los alrededores de la ciudad orensana, con los derechos jurisdiccionales derivados de su condición señorial, derechos eclesiásticos y el cobro de alcabalas reales ${ }^{32}$.

Tal como ha sido demostrado para la diócesis orensana ${ }^{33}$, la mayor parte de estos prelados no son de origen gallego y los que sí lo son suelen proceder de linajes nobles que están protagonizando la expansión patrimonial a que hacíamos mención más arriba ${ }^{34}$. Y esta dinámica habrá de continuar durante el

${ }^{30}$ Para la composición de la hacienda episcopal luguesa durante el siglo XVI, vid. María de las Nieves Peiró Graner, El señorío episcopal lucense en el siglo XVI. Estructura y administración, Lugo, Diputación Provincial de Lugo, 1998; y para la justicia señorial del obispo lugués en esta misma centuria, María López Díaz, Señorío y Municipalidad..., parte 2. ${ }^{\text {, }}$, p. 213 y ss. Asimismo, para los abundantes foros otorgados por el obispo y el cabildo catedralicio lucenses en el último cuarto del XIV, vid. María José Portela Silva y José García Oro, La Iglesia y la ciudad de Lugo en la Baja Edad Media. Los señoríos, las instituciones, los hombres, Santiago de Compostela, Instituto de Estudios Gallegos Padre Sarmiento, 1997, p. 474 y ss.

${ }^{31}$ Estos diecisiete obispos orensanos son: Alfonso de Noia (1361-1367), Juan Martínez de la Sierra (1367-1370), Juan García Manrique (1371-1375), Martín (1375-1381), Pascual García (1382-1390), Diego Anaya Maldonado (1390-1392), Pedro Díaz (1392-1408), Francisco Alfonso (1408-1419), Alfonso de Cusanca (1420-1424), Álvaro Barreguín (1424-1425), Diego Rapado (1425-1442), Juan de Torquemada (1442-1445 y 1463-1468), García Martínez de Baamonde (1445-1447), Pedro de Silva (1447-1461), Alonso López de Valladolid (1466-1468), Juan González de Deza (1469) y Diego de Fonseca (1470-1496). Vid. María José Portela Silva, “Apéndice. 1. Episcopologio auriense” in José García Oro (coord.), Historia de las diócesis..., cit., vol. 15 , Tercera parte: La Iglesia de Orense, p. 623-624.

${ }^{32}$ Anselmo López Carreira, A cidade de Ourense no século XV. Sociedade urbana na Galicia medieval, Ourense, Diputación Provincial de Ourense, 1998, p. 322; y Francisco J. Pérez Rodríguez, "La diócesis de Orense: de la reforma gregoriana al Concilio de Trento (siglos XII-XVI)" in José García Oro (coord.), Historia de las diócesis..., cit., vol. 15, Tercera parte: La Iglesia de Orense, p. 452-453.

${ }^{33}$ Anselmo López Carreira, A cidade de Ourense no século XV ..., cit., p. 324.

${ }^{34}$ Un buen ejemplo de ello lo tenemos en el arzobispo compostelano Rodrigo de Moscoso (1367-1382), perteneciente al linaje Moscoso que da lugar a la citada Casa de Altamira. Vid. la 
siglo $\mathrm{XVI}^{35}$. Se trata de una cuestión importante que debemos tener en cuenta, ya que los cabildos catedralicios se han convertido en un buen destino para colocar a algunos de los segundones de estos mismos linajes, dando lugar a una situación que se habrá de mantener en siglos posteriores para dar entrada a los segundogénitos de la nobleza provincial gallega ${ }^{36}$, si bien el marco cronológico de nuestro trabajo no va más allá de las primeras décadas del siglo $\mathrm{XVII}^{37}$. Los trabajos en que se plantea el estudio de los cabildos catedralicios gallegos y los ingresos que deben percibir sus mesas capitulares entre 1369 y 1478, permiten constatar que en el de Tui, las dignidades y canonjías catedralicias fueron entregadas en ocasiones a familiares o personas de confianza del obispo o de otros sujetos que ya contaban con un cargo; y que, por su parte, en el auriense sus integrantes mantienen lazos familiares con la fidalguía y los

genealogía de este linaje elaborada por Eduardo Pardo de Guevara, "Parentesco y nepotismo. Los arzobispos de Santiago y sus vínculos familiares en los siglos XIV y XV" in Ramón Yzquierdo Perrín (ed.), Los coros de catedrales y monasterios: arte y liturgia, A Coruña, Fundación Pedro Barrié de la Maza, 2001, Tabla IV, p. 114-115 y también p. 75-85.

${ }^{35}$ Entre 1516 y 1556, sólo 2 de los 27 obispos que logran situarse al frente de alguna de las cinco iglesias catedrales gallegas son oriundos de este territorio, siendo mayoría los de origen castellano (18); este predominio de los mitrados procedentes de Castilla continúa entre 1556 y 1598, con 21 frente a sólo 1 de origen gallego sobre un total de 31 (vid. Domingo L. González Lopo, "El episcopado gallego...", cit., p. 146-150 y "El alto clero gallego...", cit., p. 327). Compárense estos resultados con los de 11 diócesis de Castilla y León en 1556-1699, donde también el 64,5\% de los obispos electos proceden de las dos Castillas y León, y apenas un 4,5\% son de Galicia (vid. Maximiliano Barrio Gozalo, Los obispos de Castilla y León..., cit., p. 57, Cuadro 5). Un examen exhaustivo de la sociología del episcopado español durante la segunda mitad del siglo XVI y todo el XVII, en Maximiliano Barrio Gozalo, "La jerarquía eclesiástica en la España moderna. Sociología de una élite de poder (1556-1834)", Cuadernos de Historia Moderna, 25 (2000), p. 17-59.

${ }^{36}$ También los linajes nobles castellanos estuvieron interesados en situar a sus segundones en los cabildos catedralicios. Vid. en relación con los Arellano, señores de Cameros y condes de Aguilar, y los Mendoza, señores de Almazán, Máximo Diago Hernando, "El factor religioso...", cit.,p. 15-17 y "El poder de la nobleza...", cit., p. 537-538. Para el cabildo catedralicio de Cuenca en los siglos XIV y XV, vid. Jorge Díaz Ibáñez, "Las relaciones Iglesia-Nobleza...”, cit., p. 301-306; y para el de Toledo en el último cuarto del XVI, Henar Pizarro Llorente, "Los miembros del cabildo de la catedral de Toledo durante el arzobispado de Gaspar de Quiroga (1577-1594)", Hispania Sacra, 126 (2010), p. 563-619.

${ }^{37}$ El cabildo catedralicio gallego cuyo origen social de sus integrantes ha sido estudiado sistemáticamente para el siglo XVI es el de Santiago. Vid. Arturo Iglesias Ortega, La catedral de Santiago de Compostela y sus Capitulares: funcionamiento y sociología de un cabildo, A Coruña, Diputación Provincial de Coruña, 2012, p. 405 y ss. 
sectores acomodados de la ciudad de Ourense ${ }^{38}$. Asimismo, los ingresos de los capitulares tudenses estaban compuestos por el cobro de rentas forales y derechos jurisdiccionales y eclesiásticos (la renta asignada a cada cargo y la tercera parte que le correspondía del diezmo ingresado por las iglesias parroquiales de su diócesis); una imagen trasladable al cabildo orensano, pues las rentas forales representan aquí la base de la riqueza de sus integrantes, percibiendo éstos, además, rentas jurisdiccionales y eclesiásticas (renta asignada a cada miembro y diezmo parroquial ${ }^{39}$. La combinación del factor procedencia -esto es, la filiación de los capitulares con la nobleza local-con el factor económico -unos ingresos basados en rentas territoriales y la percepción del diezmo- debió de jugar un papel importante en la relación no siempre cordial que mantuvieron los obispos con los cabildos de sus iglesias catedrales, durante lo poco más de cien años que median entre las dos fechas señaladas; por lo que fueron habituales los episodios de desencuentro entre ambos por intereses opuestos ${ }^{40}$, de los cuales podemos citar, como ejemplo, para poco después, la oposición con que se encontró el obispo de Lugo Pedro de Ribera (1500-1530), por parte del cabildo catedralicio, cuando decide promover "una reforma a fondo de la vida eclesiástica" en su diócesis en 1500, que necesariamente pasaba por limitar la intromisión de la nobleza en los beneficios parroquiales ${ }^{41}$.

Las casas nobles gallegas dedicaron no pocos esfuerzos a apropiarse de este importante patrimonio, de triple naturaleza territorial, señorial y eclesiástica ${ }^{42}$,

${ }^{38}$ Vid., respectivamente, María del Carmen Sánchez Carrera, El Bajo Miño en el siglo XV..., cit., p. 231 para Tui; y Anselmo López Carreira, A cidade de Ourense no século XV..., cit., p. 320-321 para Ourense.

${ }^{39}$ María del Carmen Sánchez Carrera, El Bajo Miño en el siglo XV..., cit., p. 232; Anselmo López Carreira, A cidade de Ourense no século XV ..., cit., p. 317; y María Luz Ríos Rodríguez, "Las iglesias de la Tierra del Cabildo de la diócesis auriense a fines del s. XV" in Camilo Fernández Cortizo et al. (eds.), Universitas. Homenaje a Antonio Eiras Roel, Tomo I. Historia, Santiago de Compostela, Universidad de Santiago de Compostela, 2002, p. 111-131.

${ }^{40}$ Vid. para Santiago, José García Oro, "La diócesis de Compostela en el régimen de cristiandad (1100-1550). De Gelmírez a Fonseca" in José García Oro (coord.), Historia de las diócesis..., cit., vol. 14, Primera parte: La Iglesia de Santiago de Compostela,p. 107, 114 y 162; para Ourense, Anselmo López Carreira, A cidade de Ourense no século XV ..., cit., p. 322-323; y para Tui, Ofelia Rey Castelao, "La diócesis de Tuy en la época moderna”, in José García Oro (coord.), Historia de las diócesis..., cit., vol. 14, Segunda parte: La Iglesia de Tuy-Vigo, p. 606-607.

${ }^{41}$ Vid. José García Oro, Señorío y nobleza..., cit., p. 216-217; y Ofelia Rey Castelao, "La diócesis de Lugo en la época moderna" in José García Oro (coord.), Historia de las diócesis..., cit., vol. 15, Primera parte: La Iglesia de Lugo, p. 112-113.

${ }^{42}$ Esta triple división del patrimonio de las mesas episcopales gallegas coincide con el de las 11 diócesis de Castilla y León estudiadas por Maximiliano Barrio Gozalo, sin que ninguna de ellas llegue al nivel de ingresos del arzobispo compostelano. Vid. Los obispos de Castilla y 
que pertenecía al alto clero catedralicio; un patrimonio no siempre cuantificable, sometido a oscilaciones y que exigía a sus titulares de considerables esfuerzos administrativos, aunque sea escasa la documentación administrativa que se ha conservado en los archivos históricos con fondos documentales procedentes de las mesas episcopales y capitulares gallegas para 1369-1478 En ocasiones, las relaciones de parentesco con algunos mitrados y capitulares propiciaron el trasvase; en otras, fue la simple ocupación de bienes eclesiales que eran usurpados -tal como ha señalado Manuel Mosquera en relación con el caso lugués ${ }^{44}$-; y también en otras era la necesidad de defender estos dominios frente a potenciales rivales la que facilitaba su cesión por parte del estamento eclesiástico. Pero, al margen de las motivaciones que puedan subyacer en cada caso concreto, una de las consecuencias que se derivan del proceso, y que realmente era la que más preocupaba a los señores eclesiásticos, radica en el hecho de que, con el tiempo, los nobles intentaron patrimonializarlos como suyos propios, ignorando incluso las obligaciones contraídas con la institución que se los había cedido. En lo que se refiere específicamente a los beneficios eclesiásticos, a tenor de la documentación conservada para la diócesis compostelana, cinco de sus siete obispos que hemos visto procedieron a ceder en feudo entre 1371 y 1463 , a algunos de estos nobles, generalmente en pago por sus servicios prestados, el señorío sobre el territorio comprendido por una o varias feligresías rurales de su diócesis, incluyendo "todas suas dereituras que lles perteesçen e perteesçer deven en qualquer maneira" y mandando "aos moradores das ditas feligresias e de cada hua delas, e pobladores que ben e conplidamente vos recudan" ${ }^{45}$. Allanaban con ello el camino para

León..., cit.,p. 116 y ss. Para la importancia del diezmo y su reparto en el arzobispado de Granada, vid. Rafael Marín López, "Un memorial de 1528 al arzobispo de Granada, Gaspar de Ávalos, sobre las rentas y la administración del arzobispado", Historia, Instituciones, Documentos, 23 (1996), p. 357-383.

${ }^{43}$ Para la diócesis de Ourense, vid. María Beatriz Vaquero Díaz, Libro das posesións do cabido Catedral de Ourense (1453). Edición, transcrición e índices, Vigo, Universidad de Vigo, 2005; para la de Santiago, Mercedes Vázquez Bertomeu, La Hacienda Arzobispal..., cit., p. 151 y ss. y A Igrexa de Santiago contra 1500 (O Libro de Subsidio), Santiago de Compostela, Lóstrego, 2003, y Ángel Rodríguez González (ed.), O Tumbo Vermello..., cit.; y para Tui, el libro de rentas y gastos del cabildo para mediados del siglo XV que cita María del Carmen Sánchez Carrera, El Bajo Miño en el siglo XV..., cit., p. 232.

${ }^{44}$ Manuel Mosquera Agrelo, "La diócesis de Lugo en la Edad Media" in José García Oro (coord.), Historia de las diócesis..., cit., vol. 15, Primera parte: La Iglesia de Lugo, p. 89-90.

${ }^{45}$ Ángel Rodríguez González, "Documentación medieval del Archivo Histórico Diocesano de Santiago: Libro de feudos de diferentes bienes, feligresías, cotos y jurisdicciones", Compostellanum, XXXVII (1992), p. 373-462. 
que estos nobles accediesen al patronato sobre dichas iglesias parroquiales y los derechos a éstas anejos, entre los cuales figura la parte que le correspondía en el reparto decimal; si bien debemos insistir en que tan solo se trata de datos relativos únicamente a una de las cinco diócesis gallegas, eso sí, la más importante.

Todavía no se ha realizado un estudio de síntesis que permita conocer el alcance en cifras de este proceso para el conjunto de las cinco iglesias catedrales gallegas, ni monográficamente para cada una de ellas por separado, por lo que tampoco es posible valorar cuántas fueron en total las iglesias parroquiales y beneficios eclesiásticos que acabaron entonces en manos de las casas nobles, ni qué volumen llegaron a aportar estos ingresos a las haciendas nobiliarias -en buena medida debido a limitaciones heurísticas tanto de los fondos documentales eclesiásticos (catedralicios y diocesanos) como de los nobiliarios-; y dicha tarea tampoco ha sido contemplada como objetivo en el presente trabajo $^{46}$. Baudilio Barreiro ha calculado para la diócesis de Ourense en 1489, sobre un total de 126 parroquias, que le correspondería el derecho de presentación al obispo en el $7 \%$ de ellas, a los nobles titulados en el 12\%, a otros laicos en el $13 \%$, a monasterios en el $40 \%$ y a otras personas y entidades en el $9 \%{ }^{47}$.

${ }^{46}$ En cambio, sí disponemos de datos para mediados del siglo XVIII, en lo que se refiere al patronato en la diócesis de Santiago y al reparto del diezmo para el conjunto de Galicia. En 1748 , le corresponde a la jerarquía de la iglesia secular el $23 \%$ del patronato sobre los 1.038 curatos de la diócesis compostelana, a la nobleza el 15\%, a mayorazgos y otros laicos el $28 \%$ y a los monasterios el 33\% (vid. Pegerto Saavedra Fernández, "A rede parroquial desde finais do século XV a mediados do XIX" in Fernando García Pazos (coord.), A parroquia en Galicia. Pasado, presente e futuro, Santiago de Compostela, Xunta de Galicia, 2009, p. 97). En relación con el reparto del diezmo en Galicia a mediados del siglo XVIII, la mayor parte del mismo va a parar a manos de los párrocos $(59,7 \%)$, mientras que los obispos perciben el 3,2\%, los cabildos catedralicios el $13,1 \%$, el bajo clero el $2,4 \%$, el clero regular el $8,9 \%$, las órdenes militares el $1,4 \%$ y nobles e hidalgos juntos el 9,1\% (vid. Ofelia Rey Castelao, "El reparto social del diezmo en Galicia”, Obradoiro de Historia Moderna, 1 (1992), p. 145-162).

${ }^{47}$ Vid. Baudilio Barreiro Mallón, "Clero rural y religiosidad popular en la Galicia de tiempos de Carlos V" in Antonio Eiras Roel (coord.), El Reino de Galicia..., cit., p. 833 y "La diócesis de Orense en la Edad Moderna" in José García Oro (coord.), Historia de las diócesis..., cit., vol. 15, Tercera parte: La Iglesia de Orense, p. 487. Para los motivos que llevan a la elaboración de dicha fuente, María Luz Ríos Rodríguez, "La preparación de la reforma en Galicia. Alonso Carrillo de Albornoz y la diócesis auriense en 1489", Espacio, Tiempo y Forma. Serie III, Historia Medieval, 13 (2000), p. 325-339. A diferencia de lo que acontece en la diócesis orensana, no se dispone para las otras cuatro gallegas de una visita pastoral realizada al mismo tiempo para todo su territorio o la mayor parte de éste durante el siglo XV e inicios del XVI, sino de visitas parciales hechas a un conjunto de parroquias con cronologías diversas, lo cual dificulta la medición en porcentajes del derecho de presentación a lo largo de este período. En Mondoñedo se realizaron 
Pero de lo que no cabe duda es que su resultado debió de ser cuando menos preocupante para el alto clero catedralicio, tal como se desprende de su reacción a partir de 1478. Mientras que éste aspiraba a que retornasen a sus mesas episcopales y capitulares los beneficios eclesiásticos cedidos, para sacar provecho de los derechos que éstos generaban; por su parte, los nobles, que tras haber accedido a dichos bienes, estaban comenzando a amortizarlos en sus mayorazgos, deseaban conservarlos a toda costa para poder hacer frente a los elevados gastos a que estaban obligados para mantener la clientela integrada en sus Casas, y proyectar nuevas ampliaciones patrimoniales basadas en el mercado matrimonial ${ }^{48}$. El conflicto era pues inevitable.

La postura defendida conjuntamente por los nobles e hidalgos que detentaban las cotas de poder más elevadas en Galicia y estaban en "antigua posesión" de dichos beneficios, fue consensuada en la reunión que se celebró en la villa de Melide en 11/VIII/1482 y el pleito-homenaje que concertaron ese mismo día cerca de la Porta da Pena de la ciudad de Santiago de Compostela, por los cuales se comprometieron a poner límite a los excesos nobiliarios cometidos sobre los beneficios eclesiásticos de las cinco iglesias catedrales desde 1480 en adelante, a cambio de que las correspondientes autoridades diocesanas les ayudasen a conseguir la dispensa papal que precisaban para continuar usufructuando los beneficios objeto de disputa ${ }^{49}$. Ni que decir tiene que los exce-

algunas de éstas en 1406, 1452, 1456, 1467, 1479, 1510, 1523 y 1527 (vid. José Miguel Andrade Cernadas, "La sede de Mondoñedo en los siglos XII-XV" y Baudilio Barreiro Mallón y Ofelia Rey Castelao, "La diócesis de Mondoñedo en la Edad Moderna" in José García Oro (coord.), Historia de las diócesis..., cit., vol. 15, Segunda parte: La Iglesia de Mondoñedo-Ferrol, p. 245 y 271 respectivamente). En Santiago, en 1502 se visitaron 30 parroquias del arcedianato de O Salnés y en 1510 otras 10 del arcedianato e Cornado (vid. Baudilio Barreiro Mallón, "Clero rural y religiosidad popular...", cit., p. 826 y "La diócesis de Santiago en la época moderna" in José García Oro (coord.), Historia de las diócesis..., cit., vol. 14, Primera parte: La Iglesia de Santiago de Compostela, p. 181; y Domingo L. González Lopo y Antonio Presedo Garazo, “A visita pastoral de Juan Manxón ó arcediagado de Cornado en 1519”, Cuadernos de Estudios Gallegos, 110 (1998), p. 31-72).

${ }^{48}$ Antonio Presedo Garazo, A Fidalguía Galega. Estudos sobre a reprodución social dos fidalgos na Galicia Moderna, Santiago de Compostela, Lóstrego, 2008, p. 24-36, y "Los logros materiales y simbólicos de una mujer noble en Galicia a comienzos de la Época Moderna: doña Violante de Andrade (c.1484-1538)", Semata. Ciencias Sociais e Humanidades, 20 (2008), p. 203-208.

${ }^{49}$ Asistieron a esta reunión y otorgaron el mencionado pleito-homenaje todas las casas condales y principales linajes nobiliarios que entonces destacaban en Galicia. Dos ediciones de ambos acuerdos, que darán lugar a una sola pieza documental, en José García Oro, Señorío y nobleza..., cit., doc. n. ${ }^{\circ}$ XI, p. 258-262; José García Oro y María José Portela Silva, La Casa de Altamira..., cit., p. 564-570. 
sos también habían sido cometidos en contra de los eclesiásticos presentados por los propios nobles e hidalgos para ejercer la cura de almas en aquellas parroquias cuyo derecho de presentación les correspondía, tal como reconocía don Bernardino Pérez Sarmiento, I conde de Ribadavia (1470-1522), en su testamento otorgado once años después, en 07/X/1493:

"por quanto yo he levado algunas cosas de los clérigos de Gallizia, de los clérigos que a mi heran de presentar por razón de la dicha presentaçión, mando que mis testamentarios requieran a los dichos clérigos de mi parte se les rueguen que me lo perdonen. E sy non lo quisieren faser, mando que, faziendo juramento sobre lo que contra su voluntad les llevé, que gelo paguen" ${ }^{50}$.

La fecha de 1480 posee una relevancia destacada en relación con la cuestión que nos ocupa, puesto que representa el hito cronológico que marca el inicio del proceso de apaciguamiento y control de los linajes nobiliarios en Galicia por parte de los monarcas castellanos, quienes, en las cortes celebradas en Toledo ese mismo año, apostaron por afianzar su poder en este territorio a través del nombramiento de un gobernador auxiliado por un alcalde mayor -tres a partir de 1486 - encargados de hacer cumplir la justicia real ${ }^{51}$. No es de extrañar, por tanto, que, ante tal panorama, los nobles optasen por asociarse para velar por sus intereses, tras percatarse del peligro evidente que supondría el hecho de que llegasen a prosperar las reclamaciones presentadas en su contra, ante los delegados regios, por parte del estamento eclesiástico. El éxito de éste traería consigo menores recursos económicos, y, en consecuencia, la disminución de sus posibilidades para conservar sus clientelas privadas, viendo con ello mermada su capacidad de actuación sobre el terreno; toda vez que una parte notable de dichos recursos se sustentaba sobre los ingresos que obtenían del patrimonio eclesiástico, y muy especialmente del aporte beneficial.

${ }^{50}$ Gonzalo F. Fernández Suárez, La Nobleza Gallega..., cit., doc. n. 48, p. 547.

${ }^{51}$ Entre 1494 y 1514 se sientan las bases para la consolidación de la Real Audiencia de Galicia, a partir del anterior tribunal especial del gobernador y sus alcaldes mayores. Vid. Laura Fernández Vega, La Real Audiencia de Galicia. Órgano de gobierno en el Antiguo Régimen (1480-1808), A Coruña, Diputación Provincial de Coruña, 1982, vol. 1, p. 101-117; y Antonio Eiras Roel, "Sobre los orígenes de la Audiencia de Galicia y sobre su función de gobierno en la Época de la Monarquía absoluta", Anuario de Historia del Derecho Español, LIV (1984), p. 326-345. 
Es evidente que en los años iniciales del proceso la nobleza llevaba las de perder, no sólo porque los Reyes Católicos se habían planteado seriamente acabar con las arbitrariedades que sus integrantes habían cometido y el desgobierno que habían generado ${ }^{52}$, sino porque el pago del subsidio con que podían contribuir las haciendas diocesanas a unas arcas reales necesitadas de liquidez, representaba un argumento de peso a tener en cuenta a la hora de atender las reclamaciones presentadas por obispos y cabildos ${ }^{53}$. Según se desprende de las investigaciones realizadas para el arzobispado de Santiago, esta diócesis aportó dicha carga ese mismo año de 1482, y volvería a hacerlo otras dos veces más en la década de los años noventa ${ }^{54}$; además, su mitrado hizo un notable esfuerzo administrativo para averiguar cuáles eran los ingresos de que disponía la hacienda arzobispal, tal como acredita la elaboración del libro de recaudación de 1481-1483 ${ }^{55}$. En este contexto, el viaje que realizaron los monarcas a Galicia en 1486, no sólo contribuyó a sentar las bases para la futura recuperación de las haciendas monásticas de la mano de la reforma del monacato gallego, claramente en detrimento de algunos nobles ${ }^{56}$; sino también a que el clero secular se sintiese más amparado a la hora de defender sus intereses. El prelado compostelano encargó la composición de un nuevo libro de recaudación en 1486-149157; por su parte, en la diócesis de Ourense se dieron pasos decisivos para preparar la ansiada reforma eclesiástica, tal como acredita la redacción del tumbo de beneficios de dicho obispado en $1489^{58}$; y algunos clérigos que ejercían la cura de almas presentaron sus quejas ante la justicia real en caso de ser agredidos o despojados de la posesión de sus bene-

${ }^{52}$ María del Carmen Saavedra Vázquez, "Isabel I y Galicia: la pacificación del reino y su contribución a la política monárquica" in María Victoria López-Cordón y Gloria Franco (coords.), La Reina Isabel y las reinas de España: realidad, modelos e imagen historiográfica, Madrid, Fundación Española de Historia Moderna, 2005, p. 263-265.

${ }^{53}$ A lo cual habría que añadir el empréstito eclesiástico que habían aportado algunas catedrales castellanas en 1475-1476, durante el conflicto civil. Vid. Pablo Ortego Rico, "Las riquezas de la Iglesia al servicio del poder monárquico: los empréstitos eclesiásticos en la Castilla del siglo XV”, En la España Medieval, 35 (2012), p. 145-176.

${ }^{54}$ Mercedes Vázquez Bertomeu, A Igrexa de Santiago ..., cit., p. 45.

${ }^{55}$ Mercedes Vázquez Bertomeu, La Hacienda Arzobispal..., cit., p. 151 y ss.

${ }^{56}$ Antonio Presedo Garazo, "Las casas nobles gallegas...", cit., p. 237-243

${ }^{57}$ Mercedes Vázquez Bertomeu, La Hacienda Arzobispal..., cit., p. 225 y ss.

${ }^{58}$ María Beatriz Vaquero Díaz, "Os beneficios eclesiásticos do arcediagado da Limia (Diócese de Ourese) a finais do século XV”, Lethes, 9 (2007-2008), p. 39; y María Luz Ríos Rodríguez, "La preparación de la reforma en Galicia...", cit., p. 325-339. 
ficios $^{59}$. Incluso los propios monarcas obtuvieron una bula de Inocencio VIII en diciembre de 1487 ("Inter curas multiplices") que les daba facultad para instituir una nueva organización beneficial, aunque esta medida no llegaría a prosperar por la oposición de los señores gallegos ${ }^{60}$.

Sin embargo, cuando en 1489, don Alonso Carrillo de Albornoz, obispo de Catania, comenzó la difícil tarea de reformar "la vida eclesiástica gallega" y se encontró con la polémica surgida en torno a la cuestión beneficial, los Reyes Católicos optaron por tener en cuenta los argumentos esgrimidos por las dos partes enfrentadas. El retorno de la totalidad de los beneficios a manos de las instituciones eclesiásticas supondría, en la práctica, serios obstáculos para la mayor parte de las casas nobles e hidalgas que se habían reunido en Melide siete años antes, al representar su colapso económico; así que era preciso optar por una solución que permitiese alcanzar una situación de equilibrio, por precario que fuese, máxime después de haber comprobado cómo algunas de estas casas habían comenzado a ponerse al servicio de la monarquía ${ }^{61}$. La bula emitida por el papa Alejandro VI cuatro años después, en 1493 (“Apostolicae Sedis providentia”), a petición de los monarcas, permitió que los nobles gallegos implicados en la disputa pudiesen acceder a la dispensa que precisaban para continuar usufructuando dichos beneficios; pero lejos de zanjar el asunto, al contrario, esta medida lo prorrogó, ya que permitía la continuidad a aquellos que pudiesen demostrar su posesión por espacio de más de cuarenta $a_{n}{ }^{62}{ }^{2}$. Las causas promovidas por ambas partes habrán de continuar cuando alguna de ellas vea menoscabados sus intereses, principalmente por parte de las instituciones eclesiásticas, reiterando en sus reclamaciones presentadas ante la justicia ordinaria los argumentos ya conocidos: para el clero, el usufructo beneficial en manos de los nobles obedecía a un proceso de apropiación indebida, no exento del empleo de violencia por parte de aquéllos; mientras que, en el extremo opuesto, los patronos nobiliarios alegaban que la pérdida de dicho usufructo representaría inevitablemente perjuicios irreparables para sus Casas.

59 Algunos ejemplos referidos al cura de Santiago de Arteixo (diócesis de Santiago) en 13/X/1486, al cura de san Martiño de Tiobre (diócesis de Santiago) en 12/VI/1497, y al capellán de santa María de Faro (diócesis de Mondoñedo) en 26/X/1493, en José García Oro, Don Fernando de Andrade..., cit., p. 244-245, 257 y 261-262.

${ }^{60}$ Laura Fernández Vega, La Real Audiencia..., cit., vol. 2, p. 204.

${ }^{61}$ Vid., entre otros, José García Oro, Don Fernando de Andrade..., cit., p. 77 y ss.; y Antonio Presedo Garazo, Nobleza y régimen señorial..., cit., p. 76-77.

${ }^{62}$ José García Oro, Señorío y nobleza..., cit., p. 213-214; y Laura Fernández Vega, La Real Audiencia..., cit., vol. 2, p. 204. 
En algunos casos, hubo lugar para el acuerdo, como el que suscribieron a inicios del siglo XVI, en 19/IV/1504, don Rodrigo Osorio de Moscoso, II conde de Altamira (1504-1510), y el arcediano de Trastámara -diócesis de Santiago de Compostela-, por el cual el primero se comprometía a "que no ynpedirá las posesiones de los benefiçios que de aquí adelante vacaren en su tierra que sean presentaçión del dicho arçediano, e sy sus merinos las ocuparen que las hará desocupar" ${ }^{63}$. Mientras que en otros, la justicia real tuvo que tomar cartas en el asunto para garantizar, incluso, que la autoridad episcopal pudiese actuar en tierras de señorío laico con el objeto de poder censurar el comportamiento inadecuado del bajo clero secular; tal como se desprende de la real provisión emitida por la reina Juana I en una fecha próxima a la del caso anterior, en 18/II/1507, en la que ordena a la Real Audiencia de Galicia que apoye al obispo de Lugo contra don Fernando de Andrade, conde de Vilalba (1490-1540), quien, al impedir la intervención episcopal en sus señoríos, contribuía a que "los clérigos del dicho obispado que caen en la tierra del dicho Conde (...) tienen atrevimiento de hacer muchos delitos que no harían, si supiesen qu'el dicho Obispo e sus ofiçiales tenían libertad de castigallos" $"$.

En apenas una década que media entre 1482 y 1493, la nobleza gallega había pasado de una posición de incertidumbre a otra bien distinta de cierta seguridad, al haber garantizado los ingresos que obtenía de los beneficios parroquiales. Gracias a ello, a comienzos del siglo XVI, y tras haber recibido dos nuevas cédulas reales que le amparaban en dicha posesión -en 23/III/1510 y $28 / \mathrm{I} / 1517^{65}$-, algunas de las casas nobles de mayor abolengo implicadas en esta polémica, todavía estaban en condiciones de hacer frente al elevado gasto que se derivaba del mantenimiento de su clientela y su oneroso tren de vida, a pesar de los efectos provocados por la restauración de las haciendas monacales. Pero lejos de haber llegado a su fin, la disputa inició una nueva etapa en la que los obispos gallegos mostrarán una desigual capacidad de reacción frente a los nobles.

${ }^{63}$ Doc. edit. por José García Oro y María José Portela Silva, La Casa de Altamira..., cit., p. 577.

${ }^{64}$ Doc. edit. por José García Oro, Don Fernando de Andrade ..., cit., p. 279-280.

${ }^{65}$ Archivo Histórico Universitario de Santiago (AHUS), Bienes Nacionales, Fondo Antiguo de san Martiño Pinario, leg. 74/75. 


\section{Segunda y decisiva etapa, $1520-1563 / 70$}

El 19 de mayo de 1520, el joven monarca Carlos I (r.1516-1556) dictó una real cédula por la cual defendía y amparaba a los nobles gallegos en el usufructo de los beneficios que habían heredado de sus antepasados ${ }^{66}$. Pese al continuismo que se aprecia en relación al resultado por el que se habían decantado sus abuelos maternos tres décadas atrás, su decisión fue tomada en un contexto bien diferente, toda vez que su reinado coincide con la expansión de la reforma protestante en el continente europeo y, asimismo, un aumento y reforzamiento del poder monárquico. Aunque todavía habrá que aguardar a que finalice el Concilio de Trento en 1563, reinando su hijo Felipe II (r.1556-1598), para que el episcopado gallego se implique más activamente en la reforma del bajo clero secular ${ }^{67}$, algunos prelados que se hallaban al frente de las sedes galaicas incrementaron su labor pastoral después de 1521, con la celebración de sínodos que daban continuidad a los que ya se venían promoviendo desde el último tercio del siglo $\mathrm{XV}$, en los cuales se prestó especial atención al papel que debían desempeñar los sacerdotes encargados de ejercer la cura de almas en la extensa red parroquial gallega, para cuyo cometido debían disfrutar de una congrua que garantizase su decente sustentación, cuestión que, una vez más, remitía directamente al usufructo de los beneficios parroquiales $^{68}$.

Por otra parte, tampoco debemos olvidar que, ese mismo año, el arzobispo de Santiago, don Alonso de Fonseca III (1507-1524), tío de don Alonso de Acevedo y Zúñiga -III conde Monterrei a partir de 1526-, don Rodrigo Enríquez Osorio -II conde de Lemos (1483-1521)- y don Fernando de Andrade -conde de Vilalba- habían apoyado al joven Habsburgo cuando necesitó reunir a las Cortes de Castilla para que éstas aprobasen un servicio que ayudase a hacer frente a los elevados gastos originados por su candidatura al cetro imperial. Aunque Galicia no disponía de voto, las sesiones se celebraron en

\section{${ }^{66}$ Ibid.}

${ }^{67}$ Baudilio Barreiro Mallón, “El clero secular gallego...”, cit., p. 109; y Domingo L. González Lopo, "El alto clero gallego...", cit., p. 333-339 y "De bárbaros a devotos: la reforma tridentina en Galicia (1550-1750)" in Juan B. Amores Carredano (ed.), Religión, herejías y revueltas sociales en Europa y América, Bilbao, Universidad del País Vasco, 2008, p. 143-149.

${ }^{68}$ Domingo L. González Lopo, "El episcopado gallego...”, cit., p. 158-164; y Mercedes Vázquez Bertomeu, "Clérigos y escritura en los sínodos gallegos anteriores a Trento", Historia, Instituciones, Documentos, 29 (2002), p. 526-529. Para la situación en que se halla el clero parroquial durante el reinado de Carlos I, vid. Baudilio Barreiro Mallón, "Clero rural y religiosidad...", cit., p. 823-846. 
primavera en las ciudades de Santiago de Compostela y A Coruña, y seguramente la buena predisposición que mostraron estos nobles para que las citadas Cortes se pudiesen llegar a reunir en territorio gallego ${ }^{69}$, debió de influir para que el rey dictase esta real cédula en A Coruña el día previo a embarcarse en esa misma ciudad hacia Flandes; si bien reconocemos que tan sólo se trata de una hipótesis que todavía requerirá de un análisis de mayor calado en futuros trabajos. Lo que nos interesa realmente en relación con la cuestión que nos ocupa es que dicha decisión coincidió con esta coyuntura, y que, al igual que en tiempos de los Reyes Católicos, permitió que las casas nobiliarias que venían obteniendo parte de sus ingresos de los beneficios eclesiásticos, pudiesen continuar percibiéndolos, dando lugar a una situación tanto o más ambigua que la precedente.

El monarca, que como emperador se posicionará públicamente en contra de la reforma protestante en 1521, era el más interesado en que los obispos de sus dominios pudiesen llevar a cabo medidas encaminadas a mejorar el comportamiento del clero parroquial. De hecho, por ejemplo, no dudó en ordenar a los condes de Vilalba y Lemos en 07/V/1527 que no impidiesen al obispo de Mondoñedo realizar la inspección de los sacerdotes que, aún residiendo dentro de los límites de sus señoríos, estaban sometidos a la autoridad diocesana de este prelado ${ }^{70}$. A su vez, la reforma del monacato gallego proyectada por sus abuelos maternos culminó durante su reinado ${ }^{71}$. Por lo que se dibujó un nuevo escenario en el que, junto a las reivindicaciones de carácter económico, cobraron mayor importancia los argumentos relacionados, por un lado, con las obligaciones pastorales de los obispos y, por otro, con el correcto desempeño de las atribuciones que les correspondían a los nobles en tanto en cuanto patronos de las iglesias parroquiales. El conflicto entró pues en su etapa decisiva, la cual se habrá de prolongar hasta la llegada a Galicia de los primeros ecos del programa reformista de Trento durante el reinado filipino ${ }^{72}$. Y los resultados de su desenlace estuvieron estrechamente relacionados con la capacidad de

${ }^{69}$ José García Oro, Don Fernando de Andrade..., cit., p. 118-119.

${ }^{70}$ Doc. edit. por José García Oro, Don Fernando de Andrade ..., cit., p. 369.

${ }^{71}$ Camilo Fernández Cortizo, "Las reformas de las Órdenes de San Benito y del Císter en Galicia en tiempos de Carlos V" in Antonio Eiras Roel (coord.), El Reino de Galicia..., cit., p. 854-875.

${ }^{72}$ Sobre la aplicación del programa reformista de Trento a las iglesias castellanas durante el reinado de Felipe II, vid. José García Oro y María José Portela Silva, "Felipe II y las iglesias de Castilla a la hora de la Reforma Tridentina (Preguntas y respuestas sobre la vida religiosa castellana)", Cuadernos de Historia Moderna, 20 (1998), p. 9-32. 
reacción que tuvieron las partes implicadas para hacer frente a causas que, en algunos casos, se prolongaron por espacio de varias décadas ${ }^{73}$.

Es precisamente durante el reinado de Felipe II, ya en la segunda mitad de la centuria, donde se concentran la mayor parte de los datos que hemos logrado reunir para valorar dichos resultados, y que pasamos a comentar a continuación en el siguiente apartado. No obstante, antes es preciso que hagamos dos pequeñas matizaciones. La primera se refiere a la cronología seleccionada para nuestro examen, que coincide con la etapa final del proceso analizado y que ha estado condicionada por las propias fuentes consultadas, tanto bibliográficas como archivísticas. Éstas no siempre nos permiten comprobar qué cambios se habrían podido llegar a producir -de haberse producido- desde el tránsito del siglo XV al XVI en adelante en relación con la materia abordada, pero ya hemos indicado en páginas anteriores que se trata de una tarea compleja por falta de investigaciones e incluso de fuentes adecuadas para acometer su estudio en dicha etapa histórica, sobre todo de cara a obtener valores cuantificables $^{74}$. Así que debemos conformarnos en esta ocasión simplemente con comprobar los resultados obtenidos para la franja cronológica indicada. La segunda se halla igualmente relacionada con las fuentes que hemos manejado, puesto que éstas tampoco nos han permitido analizar cuáles fueron los resultados del conflicto en la diócesis de Tui.

\section{Balance de los resultados del conflicto en las diócesis de Ourense, Santiago, Mondoñedo y Lugo (1520-1563/70)}

En la diócesis de Ourense, según los datos procedentes de una exhaustiva visita pastoral que se realiza al poco de finalizar el concilio tridentino (1566-

${ }^{73}$ Aunque en el presente trabajo tan sólo nos hemos centrado en la disputa entre la nobleza y las iglesias catedrales por el control de los beneficios eclesiásticos, debemos tener en cuenta que el conflicto también enfrentó a la nobleza con las instituciones regulares en una cronología pareja (vid. María Jesús Baz Vicente, "Los dominios y prebendas eclesiásticas...", cit., p. 91). Podemos citar como ejemplo el beneficio parroquial de santa María de Olveira, en la diócesis de Santiago, que el monasterio cisterciense de Sobrado y su anejo de Toxosoutos ceden en foro a los abuelos maternos de don Esteban de Xunqueiras en 1379. En 1485, se renueva dicho foro a favor de este último; pero en 1528 ya es preciso otorgar una concordia entre Sobrado y su anejo con la Casa de Xunqueiras para evitar la disputa legal por dicho beneficio, a través de la cual se otorga un nuevo foro. Sin embargo, el pleito se iniciará finalmente en 1620. Vid. Anastasio S. Iglesias Blanco, A Casa de Xunqueiras nos séculos XVIII e XIX. Contribución ó estudio das economías fidalgas, Valga (Pontevedra), Ayuntamiento de Valga, 2004, p. 79-81.

${ }^{74}$ Domingo L. González Lopo y Antonio Presedo Garazo, “A visita pastoral de Juan Manxón...", cit., p. 38. 
-1569) bajo el pontificado de don Fernando Tricio de Arenzana (1565-1578) el estamento eclesiástico había sido capaz de superar esta etapa detentando el derecho de presentación sobre algo más de la mitad de las 521 iglesias parroquiales y sus anejos que entonces fueron visitadas $(53,16 \%)$. Recordemos que en 1489, según cálculos de Baudilio Barreiro, monasterios y obispo auriense habrían dispuesto del 47\%. Los resultados sintetizados en la Tabla 1 permiten comprobar cómo frente a dicho porcentaje, nobles e hidalgos controlaban algo menos de un cuarto. Con todo, debemos realizar algunas puntualizaciones. El obispo ocupaba el cuarto puesto en la relación de individuos e instituciones que actuaban como presenteros de los sacerdotes encargados de la cura de almas, con un 7,86\% de todos los beneficios (próximo, por tanto, al 7\% de 1489); mientras que el primero le correspondía a la poderosa abadía benedictina de Celanova con un $12 \%{ }^{76}$, a la cual seguían, en segundo y tercer lugar, con porcentajes casi idénticos, el no menos poderoso conde de Monterrei con un $9,98 \%{ }^{77}$, y el cabildo y dignidades catedralicias que en conjunto controlaban el 9,78\%. Con la excepción de Monterrei, el prelado orensano superaba pues a cualquier presentero laico por separado en su diócesis, incluidos los condes de Ribadavia y los de Lemos-Andrade. Tampoco debemos dejar pasar por alto que todavía a finales de la década de los años sesenta se desconocía a quién correspondía ejercer este derecho en el 6,14\% de las parroquias y anejos de la diócesis, y que, del mismo modo, había tres en las cuales éste estaba siendo objeto de pleito.

${ }^{75}$ Archivo Catedralicio de Ourense (ACOu), Visitas pastorales, Libro de visitas de los beneficios de este Obispado de Orense, año de 1566 a 1569, en que era Obispo el señor don Fernando Tricio de Arenzana.

${ }^{76}$ Un análisis detallado de los beneficios eclesiásticos del monasterio de Celanova a partir del tumbo de beneficios que se elabora para dicho obispado en 1489, en María Beatriz Vaquero Díaz, "Beneficios eclesiásticos do Mosteiro de Celanova na Diocese de Ourense a finais do século XV”, Estudios Mindoniense, 23 (2007), p. 339-369.

${ }^{77}$ Exactamente, el conde de Monterrei detenta el derecho de presentación en 52 parroquias orensanas en 1566-1569: 38 en la Dignidad de Baroncelle, 3 en la del Vicariato, 2 en la de la Chantría, 8 en la del Deanazgo y 1 en el Arcedianato de Celanova. Cuando en 1489 se elaboró el Tumbo de Beneficios de la Diócesis de Ourense, los condes de Monterrei ya ejercían entonces como patronos en una cantidad considerable de parroquias orensanas. Tal como ha señalado María Beatriz Vaquero Díaz en relación con los beneficios eclesiásticos del Arcedianato de A Limia, que incluye 51 iglesias parroquiales y un número superior a 37 anejas, les correspondía a éstos el patronato en 41 iglesias y 27 anejas. Vid. "Beneficios eclesiásticos do arcediagado da Limia...", cit., p. 39 y 42-45. 
Tabla 1 - Reparto del derecho de presentación de los beneficios parroquiales y sus anejos en la diócesis de Ourense (1566-1569)

\begin{tabular}{|c|c|c|}
\hline i. Presentación eclesiástica & n. ${ }^{\circ}$ & $\%$ \\
\hline Clero catedralicio & 94 & 18,04 \\
\hline Obispo de Ourense & 41 & 7,86 \\
\hline Cabildo y dignidades de Ourense & 51 & 9,78 \\
\hline Obispo de Santiago & 1 & 0,19 \\
\hline Cabildo de Santiago & 1 & 0,19 \\
\hline Clero regular & 147 & 28,21 \\
\hline Orden benedictina & 101 & 19,38 \\
\hline Orden cisterciense & 46 & 8,82 \\
\hline Colegiatas & 14 & 2,68 \\
\hline Abadías seglares & 22 & 4,22 \\
\hline Total presentación eclesiástica & 277 & 53,16 \\
\hline ii. Presentación laica & n. $^{\circ}$ & $\%$ \\
\hline Alta nobleza & 90 & 17,27 \\
\hline Hidalgos & 31 & 5,95 \\
\hline Señores de cotos & 7 & 1,34 \\
\hline Total presentación nobiliaria & 128 & 24,56 \\
\hline \multicolumn{3}{|l|}{ Otros casos contemplados } \\
\hline Escribanos & 3 & 0,57 \\
\hline Familias & 10 & 1,91 \\
\hline Varios presenteros laicos, identificados en parte & 6 & 1,15 \\
\hline Presenteros laicos de los cuales se desconoce su filiación estamental & 3 & 0,57 \\
\hline Presentación de laicos sin más aclaración & 23 & 4,41 \\
\hline Total presentación laica & 173 & 33,20 \\
\hline iii. Presentación por OO MM & 5 & 0,95 \\
\hline iv. Presentación por S. M. & 5 & 0,95 \\
\hline v. Presentación mixta & 18 & 3,45 \\
\hline vi. Otros & 1 & 0,19 \\
\hline vii. Beneficios cuya presentación está siendo objeto de pleito & 3 & 0,57 \\
\hline viii. Sin información/No se sabe & 32 & 6,14 \\
\hline TOTAL & 521 & 100 \\
\hline
\end{tabular}

Fuente: Elaboración propia a partir de ACOu, Visitas pastorales, Libro de visitas de los beneficios de este Obispado de Orense, año de 1566 a $1569 \ldots$ 
En la diócesis de Santiago, la labor judicial desarrollada por el arzobispo don Juan Pardo de Tavera (1524-1534) contra las principales casas nobles que habían intentado extender sus dominios a expensas de la hacienda episcopal en el transcurso de los siglos bajomedievales, obtuvo resultados favorables a su causa, tras haberse demostrado que éstas incluso se habían valido de documentación falsificada a la hora de justificar sus reivindicaciones. En este caso se puede apreciar cómo, en algunos pleitos, no sólo estaban en disputa los beneficios parroquiales, sino también la jurisdicción sobre determinados territorios procedentes de la mitra episcopal, por lo que el problema beneficial pasó a formar parte de litigios de mayor calado que se extendieron durante el resto de la centuria y comienzos de la siguiente ${ }^{78}$. Entre ellas se encuentra la casa condal más poderosa en la diócesis compostelana: Altamira, que en ca. 1528 controlaba el beneficio eclesiástico de 52 parroquias en los arciprestazgos de Amaía (1), Bama (1), Barbeiros (1), Barcala (1), Bergantiños (8), Berreo de Arriba (7), Duio (1), Entíns (1), Faro (2), Ferreiros (1), Nemancos (1), Piloño (7), Ribadulla (4), Seaia (7), Soneira (6) y Tabeirós (2) ${ }^{79}$, igualando al conde de Monterrei en la de Ourense. Los estudios realizados permiten comprobar cómo el aporte beneficial había llegado a situarse en un nivel elevado en algunas de las haciendas nobiliarias cuyos solares se hallan en el territorio comprendido por esta diócesis, por lo que su pérdida podía provocar importantes desajustes en el delicado equilibrio presupuestario de estas Casas. Así, en la de Montaos, por entonces la casa hidalga sin título más importante que había en esta diócesis, las sinecuras ${ }^{80}$ que poseía en 1526-1527 en 22 parroquias compostelanas -cantidad equivalente a las del conde de Ribadavia en la de Ourense- fueron tasadas en 221.000 maravedíes $^{81}$.

Esta última nos ofrece, además, un ejemplo muy ilustrativo de cómo también, en ciertas ocasiones, el cabildo catedralicio santiagués logró resolver

${ }^{78}$ César Olivera Serrano, "La Galicia de Vasco de Aponte: los pleitos del arzobispo Tabera contra los linajes de la Tierra de Santiago", En la España Medieval, 22 (1999), p. 285-315.

${ }^{79}$ Datos calculados a partir de la documentación editada por José García Oro y María José Portela Silva, La Casa de Altamira..., cit., p. 445-452. No se ha logrado ubicar la parroquia de san Pedro de Cibrán citada en dicho documento. A comienzos del siglo XVII no aparece en Jerónimo del Hoyo, Memorias del arzobispado de Santiago, Santiago de Compostela, 1607 (Edición a cargo de Ángel Rodríguez González y Benito Varela Jácome, Santiago de Compostela, Porto y Cía. Editores, 1950?).

${ }^{80}$ Estas sinecuras representan una parte variable de los frutos que, en algunos casos, puede rendir un beneficio eclesiástico y que no corresponde al clérigo rector encargado de la cura de almas. Así, el propietario de la sinecura y la persona o institución a quien pertenece la presentación de la cura no tienen por qué coincidir.

${ }^{81}$ AHUS, Fondos Privados, Marquesado de Montaos, caja 11, n. ${ }^{\circ} 2$. 
con éxito sus reivindicaciones frente a las casas nobles por los beneficios parroquiales de esta diócesis en el siglo XVI. En 1502, el jefe de la Casa, por entonces canónigo de la Iglesia Catedral de Santiago, había cedido a la mesa capitular de ésta las sinecuras de 25 parroquias sobre las cuales su Casa venía ejerciendo el derecho de patronato; será su hijo quien inicie la disputa judicial contra este cabildo en 1507 por 16 de ellas, resolviéndose la causa con su cesión en foro. La controversia se reanuda en el tercer cuarto de la centuria, siendo objeto de disputa 22 parroquias en 1574, y cuando en 1596 se redacta el apeo general del estado de Montaos tan sólo se reconoce a sus dueños el derecho de patronato sobre $12^{82}$. Los Mariño de Lobeira salieron igualmente malparados del pleito que les interpuso el arcediano de Trastámara, de nuevo en el tercer cuarto de la centuria, ante la Real Audiencia de Galicia, por cuya sentencia de vista, dictada en 05/VIII/1572, se condena a don Cristóbal Mariño de Lobeira y a su hijo don Paio, a restituir "al dicho arcediano (...) los frutos y rentas, diesmos y eclesiásticas derechuras que a coxido y llevadao de los casares <e> yglesarios de Santa Marina de Maroñas e San Juan de Ygrexoa e San Martino de Fontecada, (...) desde diez años a esta parte" ${ }^{83}$.

Con todo, a finales del XVI, el arzobispo compostelano tan sólo controlaba el $6 \%$ de los derechos de presentación de la cura y sinecura en su diócesis, muy por detrás del $50 \%$ que le correspondía a los titulares laicos-inclusive la nobleza-, según los cálculos efectuados por Baudilio Barreiro a partir de la visita realizada por el canónigo y cardenal Jerónimo del Hoyo en $1607^{84}$.

En la diócesis de Mondoñedo, de la misma manera que acontece en las dos precedentes, las casas nobles lograron mantener su derecho de patronato sobre las iglesias parroquiales en aquellas zonas en las cuales habían llevado a cabo su expansión durante la etapa bajomedieval, a pesar de las reclamacio-

${ }^{82}$ La pérdida de sinecuras por parte de la Casa de Montaos continuará durante el siglo XVII, ya que ésta detenta el derecho de presentación en 10 iglesias parroquiales en 1667. Hemos analizado dicho proceso en Antonio Presedo Garazo, Nobleza y régimen señorial..., cit., p. 166-170.

${ }^{83}$ José García Oro y María José Portela Silva, "Los Mariño de Lobeira en la Galicia del Renacimiento. Fortuna y desgracia de un señorío seglar del área compostelana”, Estudios Mindonienses, 19 (2003), doc. n. ${ }^{\circ}$ 46, p. 163-181, especialmente p. 168. Este pleito todavía continuará en 1610-1611 (Ibid., doc. n. ${ }^{\circ} 47$ a 59, p. 181-208).

${ }^{84} \mathrm{Si}$ únicamente se tiene en cuenta la presentación de la cura, el reparto en porcentajes experimenta pequeños cambios: el arzobispo cuenta con un 7,3\%, el cabildo compostelano un $12,3 \%$, los monasterios el $32,4 \%$, la nobleza titulada el $8,3 \%$ y el resto de presentación laica alcanza el 38,5\%. Vid. Baudilio Barreiro Mallón, "Clero rural...", cit., p. 834 y "La diócesis de Santiago en la época moderna" in J. García Oro (coord.), Historia de las diócesis..., cit., vol. 14, Primera parte: La Iglesia de Santiago de Compostela, p. 188. 
nes episcopales ${ }^{85}$. Una prueba de ello la tenemos en la parte que se ha conservado de la visita general que realizó el prelado mindoniense don Alfonso Mesía de Tovar (1612-1616) en 1614. En 72 parroquias distribuidas por los arciprestazos más orientales, el conde de Lemos y los dueños de la Casa de San Sadurniño detentaban el derecho de presentación, respectivamente, sobre en el $16,6 \%$ y el $18 \%$ de las mismas, mientras que obispo y cabildo suman el $12,5 \%{ }^{86}$. Un siglo antes, el reparto de los derechos de presentación durante el reinado de Carlos I tampoco deja lugar a dudas en O Valadouro en 1510: si el obispo controla el $8,5 \%$ de los beneficios y el cabildo catedralicio el $15 \%$, a los laicos le corresponde en conjunto el $50 \%{ }^{87}$.

Los datos que hemos calculado para la diócesis de Lugo a partir de la información que ofrece M. ${ }^{a}$ Nieves Peiró para el siglo XVI, deja tras de sí un balance igualmente poco favorable para su obispo. Éste sólo consigue percibir rentas derivadas del derecho de patronato en 39 iglesias parroquiales de las 930 pertenecientes a su diócesis (un 4,25\%), habiendo 21 arciprestazgos en los cuales no detenta este derecho ${ }^{88}$. El resultado sólo mejora sensiblemente

${ }^{85}$ Entre ellas la que José García Oro atribuye al obispo don Alfonso Suárez de la Fuente en 1499, quien habría reclamado ante la justicia real los bienes eclesiásticos que consideraba habían sido apropiados indebidamente por parte de los principales linajes nobiliarios que extendieran sus patrimonios en esta diócesis (el marqués de Astorga, el vizconde de Altamira, los condes de Altamira y de Monterrei, don Fernando de Andrade, Fernán Pérez Parragués, Fernán Sanxurxo Montenegro, Beatriz de Castro, Pedro Pardo, Pedro Vázquez de Cabarcos, Pedro Álvarez Osorio, Juan López Pardo y Álvaro Gómez de Ribadeneira); y cuya reclamación dará lugar a una cédula real, firmada a finales de ese mismo año, por la cual se emplaza a estos nobles a presentarse en Valladolid para alegar los derechos que les permitían ocupar dichos bienes (vid. José García Oro, Señorío y nobleza..., cit., p. 215-216). No obstante, ese mismo año, según el episcopologio mindoniense, ya era obispo su sucesor don Pedro de Munébrega (1498-1505). Vid. Enrique Cal Pardo, Episcopologio mindoniense..., cit., p. 239 y ss.

${ }^{86}$ Archivo Histórico Nacional (AHN), Clero Secular, Catedral de Mondoñedo, lib. 6374. Libro de la visita general del obispo Alfonso Mesía de Tovar, 1614. Documento digitalizado consultado a través de PARES (http://pares.mcu.es) en 2013.10.04. Una de esas parroquias es la de san Paio de Ferreira, cuyo derecho de presentación detenta el conde de Lemos en 1614. En 06/II/1535, Carlos I había otorgado una real provisión a favor de don Fernando de Andrade, ordenando que se respete su derecho de patronato que le corresponde sobre la tercera parte de dicho beneficio parroquial (doc. edit. por José García Oro, Don Fernando de Andrade..., cit., p. 447).

${ }^{87}$ Baudilio Barreiro Mallón, “Clero rural...”, cit.,p. 833. Según nuestros cálculos efectuados a partir de la citada visita pastoral de 1614, eran de presentación laica el 68\% de las 72 iglesias parroquiales visitadas.

${ }^{88}$ La diócesis de Lugo estaba dividida en 39 arciprestazgos, por lo que el obispo no posee el derecho de presentación en ninguna de las parroquias del 53,8\% de éstos. 
si atendemos a la presentación de la cura de almas, puesto que actúa como presentero en 81 parroquias, esto es, en un $8,7 \%{ }^{89}$.

En el territorio que comprende esta diócesis se concentra el núcleo principal del patrimonio perteneciente a la casa condal gallega más relevante en toda la Edad Moderna, esto es, la de Lemos, y asimismo, también aquí consiguieron extender parte de sus dominios las dos que le siguen en relevancia: Altamira (en el área de Castroverde y el arciprestazgo de Trasdeza) y Monterrei (en los arciprestazgos de Ulloa y Monterroso) ${ }^{90}$. Junto a ellas, habían ampliado sus patrimonios casas hidalgas de menor relieve, pero igualmente poderosas, con las cuales mantenían estrechos lazos de dependencia y compartían intereses afines, como la de Taboada, por citar un caso representativo estudiado recientemente ${ }^{91}$. La relevancia que llegaron a alcanzar los ingresos de origen parroquial en algunas haciendas nobiliarias e hidalgas, parece confirmar que era realmente mucho lo que se jugaron los sectores más elevados de la nobleza y el clero en Lugo en el transcurso de esta etapa decisiva de la disputa por los beneficios eclesiásticos, más allá del capital simbólico que podían llegar a desplegar los patronos en los templos parroquiales y del enorme poder que estos mismos detentaban merced al derecho de presentación de la cura de almas $^{92}$. Veamos algunos ejemplos. La casa condal de Altamira obtenía en

${ }^{89}$ Datos calculados a partir de María de las Nieves Peiró Graner, El señorío episcopal lucense..., p. 279-287.

${ }^{90}$ Sobre la extensión alcanzada por los dominios de las casas condales de Lemos y Monterrei, vid. María Jesús Baz Vicente, Señorío y propiedad foral de la alta nobleza en Galicia (siglos XVI-XX): La Casa de Alba, Madrid, Ministerio de Agricultura, Pesca y Alimentación, 1996, “Apéndice", p. 432 y ss. Esta misma autora ha elaborado una relación pormenorizada de los patronatos y sinecuras pertenecientes a Lemos y Monterrei en los siglos XVII y XVIII, en su trabajo "Los dominios y prebendas eclesiásticas...", cit., p. 110-117. Para Altamira, vid. José García Oro y María José Portela Silva, La Casa de Altamira..., cit., p. 451-452.

${ }^{91}$ José Luís Díaz-Castroverde Lodeiro, Morgados e xurisdiccións na Terra e condado de Taboada. Séculos XV-XVIII, Guntín (Lugo), Asociación de Amigos do Mosteiro de Ferreira de Pallares, 2012.

${ }^{92}$ En el transcurso del siglo XVI, la Casa de Quindimil presentaba, en el área de Palas de Rei, el curato de san Miguel de Quindimil y sus anejos de san Xoán de Laia, san Miguel de Maceda y santa María de A Puxeda (vid. José Manuel Vázquez Lijó, Luces sobre a Casa de Goiáns no Antigo Réxime, Boiro (A Coruña), Ayuntamiento de Boiro, 2012, p. 107, nota 2). En Taboada, la Casa de Sonán incorporó a su mayorazgo fundado en 1534 los dos tercios del beneficio sinecura de san Cibrao de Negrelos, en el arciprestazgo de Camba (vid. José Luís Díaz-Castroverde Lodeiro, El señorío de de la Casa de Sonán en su jurisdicción, gobierno y hacienda durante los siglos XVI al XX, Padrón (A Coruña), Novo Século, 1995, p. 191). Y ya más tardíamente, en el área del Deza, en la fundación del vínculo de la Casa de Brenzos, que data de 06/I/1637, se incorporó la presentación de seis curatos y sus tres anejos en el arciprestazo de Deza (vid. César 
ca.1528 170-174 fanegas de pan y un ducado por su participación en el reparto de los ingresos generados por 14 beneficios parroquiales en el arciprestazgo de Trasdeza ${ }^{93}$. En su mismo nivel estamental, aunque con datos ya más tardíos que nos remiten a la primera mitad del siglo XVIII, el diezmo representaba el $69,7 \%$ de los ingresos que percibían los condes de Monterrei en su estado de Ulloa; y en la mayordomía de Deza, entonces perteneciente a Lemos, unas 38 sinecuras aportaban el equivalente a una cantidad todavía mayor: el 81,2\% ${ }^{94}$. Entre las casas hidalgas lucenses cuyos antepasados habían asistido a la reunión de Melide de 1482, la Casa de Noceda obtenía en 1623 el 62,6\% de la renta que ingresaba en cereal de los derechos de patronato y la mitad del beneficio eclesiástico que le correspondía en iglesia parroquial de san Xoán Noceda (arciprestazgo de Ferreiros de Balboa), justo antes de iniciar su gran expansión patrimonial a partir del mercado de la tierra en 1631-165995. Por su parte, el segundo apartado en importancia en la hacienda de la Casa de Taboada estaba representado por el diezmo que le correspondía a sus dueños en 11 feligresías del arciprestazgo de Ínsoa y Taboada, el cual ascendía a 9.152 reales a la altura de $1678^{96}$.

Ahora bien, reducir la explicación del desenlace del conflicto beneficial en Lugo únicamente a una mayor concentración de patrimonios nobiliarios, sólo nos permitiría obtener una perspectiva parcial del asunto. Sin minimizar su importancia, no debemos dejar pasar por alto la capacidad de respuesta que tuvieron estas casas para seguir ante las instancias judiciales las causas que las instituciones eclesiásticas promovieron en su contra, y no sólo la mitra catedralicia, para reclamarles los bienes de naturaleza diversa -señorial, territorial y eclesiástica-que consideraban les habían sido sustraídos en esta diócesis. De hecho, ya desde la etapa precedente, la Casa de Taboada se venía esforzando por conservar la parte del beneficio sin cura que le pertenecía en Santiago de Ferroi frente al obispo lugués, consiguiendo justo ahora refrendar su posición, primero a través de una real cédula de amparo expedida a su favor por Carlos I en $25 / \mathrm{I} / 1526$, y luego con una bula pontifica otorgada a su favor en 1546 , con

Gómez Buxán, "Xenealoxías dezanas”, Descubrindo Deza.Anuario de Estudios e Investigación, 4 (2002), p. 17-18).

${ }^{93}$ Dato calculado a partir de la documentación editada por José García Oro y María José Portela Silva, La Casa de Altamira..., cit., p. 294-295.

${ }^{94}$ María Jesús Baz Vicente, Señorío y propiedad foral..., cit., p. 221, y "Los dominios y prebendas eclesiásticas...", cit., p. 93.

${ }^{95}$ Antonio Presedo Garazo, A Fidalguía Galega..., cit., p. 102-110.

${ }^{96}$ José Luís Díaz-Castroverde Lodeiro, Morgados e xurisdiccións..., cit., p. 63. 
la cual se ratificó legalmente dicha posesión beneficial ${ }^{97}$. En sentido inverso, tampoco habría que desestimar la posibilidad de que el prelado lucense se hubiese podido encontrar con más obstáculos que sus homólogos gallegos a la hora de hacer frente a estos casos de reivindicación por devolución patrimonial, que, tal como hemos indicado en páginas precedentes, solían resultar muy costosos al prolongarse sus diligencias por espacio de varias décadas. Sirva como ejemplo el pleito que sigue ante la Real Audiencia de Galicia el obispo de Lugo, don Lorenzo Asensio de Otaduy (1591-1599), contra Fernando Díaz Ribadeneria y otros, por diferentes lugares, diezmos, jurisdicciones y presentación de beneficios, iniciado en 1597 con la demanda presentada por parte del mitrado, y cuya sentencia no se dicta hasta $1696^{98}$. Debemos añadir además que, del mismo modo que acontece en las otras iglesias catedrales galaicas, el obispo lugués se habría encontrado con un cabildo catedralicio no siempre afín, integrado por capitulares que mantenían estrechos vínculos de sangre con las principales casas nobles de su diócesis, que, justo en este caso concreto, a mayores, se correspondía con la provincia que contaba con una mayor concentración de población hidalga y en la que el señorío nobiliario alcanzó una mayor extensión ${ }^{99}$.

Como resultado de todo ello, el balance del conflicto fue de nuevo aquí favorable a nobles e hidalgos, quienes lograron mantener su influencia en las parroquias luguesas. El control que continuaron ejerciendo del derecho de patronato en una parte destacada de éstas no solo les permitió seguir participando activamente en la presentación de la cura de almas, sino también en la percepción de las rentas anejas a dichos beneficios, entre las cuales destaca el porcentaje que le corresponde en el reparto decimal ${ }^{100}$. Frente a esto, el obispo contará con valores modestos en la presentación de la cura y en la participa-

${ }^{97}$ José Luís Díaz-Castroverde Lodeiro, Morgados e xurisdiccións..., cit., p. 65-69. Para el litigio que se inicia en 1526 entre la Casa de Lemos y el monasterio de Samos, por bienes que esta congregación benedictina había cedido en foro a dicha casa condal, vid. María Jesús Baz Vicente, "Los dominios y prebendas eclesiásticas...", cit., p. 88.

${ }^{98}$ AHN, Clero Secular, Catedral de Lugo, lib. 6353, concretamente, la relación de beneficios objeto de disputa en f. 19r/v. Documento digitalizado consultado a través de PARES (http:// pares.mcu.es) en 2013.10.11.

${ }^{99}$ Uno de estos linajes hidalgos que tuvieron una notable presencia en la mesa capitular luguesa a lo largo de toda la centuria fue el de los Gaioso. Vid. Eduardo Pardo de Guevara, Palos, fajas y jaqueles. La fusión de armerías en Galicia durante los siglos XIII al XVI, Lugo, Diputación Provincial de Lugo, 1996, p. 98-100.

${ }^{100}$ A mediados del siglo XVIII, la nobleza ingresa el 9,9\% del diezmo generado en la provincia de Lugo y los hidalgos el 9,3\%, superando en ambos casos por separado al conjunto del alto clero catedralicio. Vid. Ofelia Rey Castelao, "El reparto social del diezmo...", cit., p. 161, Tabla 1. 
ción del reparto del diezmo, mientras que, por su parte, el cabildo catedralicio se consolidará como un importante perceptor en el conjunto regional. No disponemos de datos relativos a qué porcentaje le pudo haber correspondido al alto clero catedralicio lugués en las rentas eclesiásticas de las parroquias cuyo patronato pertenece a casas nobles e hidalgas en el período histórico que nos ocupa; pero los valores que se conocen para el conjunto de dicha diócesis para el siglo XVIII van en esta línea. Si en 1700-1749 el obispo lugués solo presenta la cura en el 14\% de las 213 parroquias de 12 de los 39 arciprestazgos lucenses, cuando a los laicos les corresponde el 60,5\% ${ }^{101}$; en el tramo central de la misma centuria, éste no figura en la relación de mayores perceptores del diezmo en Galicia, excluidos los párrocos, capaces de superar los 10.000 reales anuales generados por tal concepto, aunque los capitulares lucenses sí ocupan un buen puesto en dicho listado -el décimo primero-, ahora bien, por detrás de los otros cuatro cabildos catedralicios gallegos ${ }^{102}$.

\section{Breve conclusión}

La disputa que mantuvo el episcopado gallego con las casas nobles e hidalgas por el control de los beneficios parroquiales posteriormente a la congregación general del clero castellano celebrada en Sevilla en 1478, se saldó favorablemente a sus adversarios. Una vez pasado el primer momento de incertidumbre, y tras haberse asociado en 1482 para defender su causa en común, los integrantes del estamento nobiliario fueron capaces de conseguir que la monarquía ratificase la situación preexistente, primero a través de la bula papal de 1493, y luego con las reales cédulas de 1510, 1517 y 1520 que amparaban a aquellos que estaban en "antigua posesión" del usufructo de dichos beneficios. Como hemos podido comprobar, fueron varias las causas que, interconectadas en ciertas ocasiones, contribuyeron a que tanto la alta nobleza como las casas hidalgas de origen tardomedieval continuasen detentando los derechos que habían conseguido en la red parroquial gallega. Su inicial capacidad de respuesta común y el esfuerzo individual de los nobles implicados en el conflicto, para hacer frente a las causas promovidas en su contra; la reacción limitada de unos obispos que por término medio estuvie-

${ }^{101}$ Isidro Dubert García, "La domesticación, la homogeneización y la asimilación de las conductas del clero gallego del Antiguo Régimen a la idealidad del modelo trentino, 1600-1850" in Javier M. Domézar y Manuel Pérez Ledesma (eds.), Antiguo Régimen y liberalismo. Homenaje a Miguel Artola. Vol. 2. Economía y Sociedad, Madrid, Alianza, 1994, p. 486.

${ }^{102}$ Ofelia Rey Castelao, "El reparto social del diezmo...”, cit., p. 162, Tabla 5. 
ron poco tiempo al frente de sus diócesis hasta medidos del siglo XVI, cuyas haciendas episcopales no daban lugar a ingresos cuantiosos, con la excepción de la de Santiago; y la relación no siempre cordial que mantuvieron estos prelados con sus cabildos catedralicios, cuyos capitulares suelen proceder de la nobleza provincial; son tres factores que intervinieron decisivamente en la resolución de los litigios y que decantaron la balanza a favor del estamento noble.

No obstante, hubo igualmente otras dos cuestiones que influyeron en la resolución de esta polémica surgida a raíz del derecho de patronato y los ingresos a que éste daba lugar, y que no podemos pasar por alto en nuestra breve conclusión. El primero atañe al propio planteamiento del conflicto, ya que no se trata en modo alguno de una disputa en la que intervinieron únicamente dos bandos enfrentados, dando lugar tan solo a una confrontación estamental entre la nobleza y el clero. Las dos iniciativas contrapuestas que promueven de manera colectiva, primero el clero en Sevilla en 1478 y luego la nobleza en Melide y Santiago de Compostela en 1482, pueden contribuir a distorsionar en parte el verdadero significado de la disputa, puesto que ni los eclesiásticos ni los nobles gallegos conformaban entonces estamentos homogéneos, sino que integran a sectores variados, incluso con una mayor diversidad compositiva en el caso del clero, con intereses opuestos dentro de cada uno de ellos. Así que cuando en 1478 el clero gallego expresó en común su causa fue para llamar la atención de la Corona y que ésta interviniese para resolver favorablemente sus reivindicaciones contra la nobleza, sin atender a las disputas que por motivos de jurisdicción señorial o derechos eclesiásticos también se habían planteado dentro del propio estamento eclesiástico desde finales del siglo XIV en adelante. Y lo mismo sucede con el pleito-homenaje secundado por todas las casas condales y principales linajes nobiliarios implicados en el asunto, ya que éste no da por zanjadas las disputas y querellas nobiliarias surgidas hasta el momento. Por tanto, nosotros nos hemos ocupado apenas de una parte del conflicto, esto es, la que implicó al alto clero catedralicio, y dentro de éste de manera muy especial a los obispos, en sus reivindicaciones contra la nobleza por motivo de su patrimonio señorial, territorial y eclesiástico; pero no debemos olvidar que también las instituciones regulares se vieron involucradas en su desarrollo, compartiendo sus reclamaciones con obispos y cabildos catedralicios ${ }^{103}$, obteniendo incluso un mejor resultado que aquellos en las diócesis

${ }^{103}$ Vid. casos citados en notas 20 y 73 . Otro ejemplo que se puede poner es el pleito que están manteniendo en 1566 el conde de Ribadavia y el monasterio cisterciense de Oseira por la presentación del beneficio eclesiástico de la parroquia de santa María de Grixoa, en la diócesis 
de Ourense en 1566-1569 (donde presentan la cura en el 32,42\% de las parroquias orensanas, incluidas aquellas que corresponden a las abadías seglares) ${ }^{104}$ y Santiago en 1607 (con un porcentaje idéntico del 32,4\%) ${ }^{105}$. Del mismo modo, tampoco deberíamos olvidar las disputas que se plantearon dentro de las propias iglesias catedrales entre obispos y capitulares, y que no fueron ajenas a la temática abordada en nuestro trabajo ${ }^{106}$. De hecho, a mediados del siglo XVIII, los cabildos catedralicios de Santiago, Tui y Mondoñedo ocupan los tres primeros puestos en la relación de mayores perceptores del diezmo en Galicia, duplicando la cantidad que por este mismo concepto percibe el señor jurisdiccional más importante que había entonces en este territorio, esto es, el arzobispo de Santiago, a quien corresponde el sexto lugar ${ }^{107}$.

La segunda cuestión atañe al papel desempeñado por la Corona. Su intervención resultó decisiva para que la nobleza lograse mantener su posición a pesar de que, en un primer momento, atendió a las demandas presentadas por el clero, coincidiendo con una coyuntura política de la que los Reyes Católicos supieron sacar provecho en beneficio de la monarquía, obteniendo de éste su legitimación en el trono castellano y apoyo para sus necesidades hacendísticas; a la vez que intentaban mitigar, y sobre todo doblegar, el poder nobiliario en un territorio en el que los integrantes de este estamento habían dado lugar a una situación de desgobierno. Una vez logrados sus objetivos, los monarcas dieron prioridad al equilibrio de fuerzas, apoyando indistintamente tanto a unos como a otros siempre que sus reclamaciones estuviesen fundamentadas conforme a derecho, así que en la práctica primó la continuidad, o si se prefiere, la vigencia del status quo precedente que favorecía claramente a la

de Ourense (dignidad de Castela). ACOu, Visitas pastorales, Libro de visitas de los beneficios de este Obispado de Orense, año de 1566 a 1569..., f. 51r. Para la intromisión de la alta nobleza y los escuderos en los beneficios eclesiásticos de la abadía benedictina de Celanova en esta misma diócesis auriense en 1489, vid. María Beatriz Vaquero Díaz, "Beneficios eclesiásticos do Mosteiro de Celanova...", cit., p. 346-347.

${ }^{104}$ Vid. supra Tabla 1.

${ }^{105}$ Baudilio Barreiro Mallón, "La diócesis de Santiago...", cit., p. 188.

106 Téngase en cuenta que en el contexto de la reforma tridentina, para que los obispos españoles fuesen capaces de llevar a cabo su objetivo principal de restaurar la disciplina eclesiástica, era preciso que previamente pusiesen límite a los abusos que también venían cometiendo algunos de sus capitulares. Un análisis de la polémica generada en las iglesias catedrales castellanas en torno a esta cuestión, en Joaquín Gil Sanjuán, "Lucha de los cabildos castellanos por su autonomía y libertad (1553-1555)", Espacio, Tiempo y Forma. Serie IV, Historia Moderna, 7 (1994), p. 275-296.

${ }^{107}$ Ofelia Rey Castelao, "El reparto social del diezmo...”, cit., p. 162, Tabla 5. 
nobleza gallega, tal como acreditan las cédulas reales de comienzos del siglo XVI.

El cambio que las Iglesias Catedrales galaicas deseaban que se produjese en este sentido se limitó finalmente a logros que no afectaron en consideración a nobles e hidalgos, a la vista de los resultados procedentes de las diócesis de Ourense, Santiago, Mondoñedo y Lugo. Éstos fueron posibles a costa del esfuerzo económico que debieron realizar las mitras catedralicias para afrontar el elevado gasto de las causas que se siguieron ante la justicia ordinaria, en ocasiones, por espacio de varias décadas, y de la tenacidad de obispos como Alfonso de la Fuente en Mondoñedo a finales del XV o don Juan Pardo de Tavera en Santiago durante la década de 1524-1534, que deseaban restaurar unas haciendas episcopales que, del mismo modo que las de monasterios, cabildos y colegiatas, habían estado sometidas a una gran presión por parte del estamento noble durante los siglos bajomedievales.

Sin embargo, cuando en el último tercio del siglo XVI se inició la primera etapa de aplicación del programa reformador del Concilio de Trento, que en la Iglesia gallega todavía se habrá de extender hasta mediados del XVII, la influencia de la nobleza en la red parroquial seguía siendo manifiesta, principalmente porque las reclamaciones del estamento eclesiástico en el contexto de la disputa beneficial no siempre prosperaron, lo cual permitió que pudiesen seguir presentando la cura de almas y participando de los ingresos que generaban dichos beneficios. 